\title{
A novel index based on planktonic copepod reproductive traits as a tool for marine ecotoxicology studies
}

\author{
Hussain Mohamed Bakr ${ }^{1}$, Laabir Mohamed ${ }^{2}$, Yahia Mohamed Nejib Daly ${ }^{1,{ }^{*}}$
}

${ }^{1}$ Department of Biological and Environmental Sciences, College of Arts and Sciences, Qatar University, PO Box 2713, Doha, Qatar

${ }^{2}$ Marbec, University of Montpellier, IRD, Ifremer, CNRS, 34095 Montpellier Cedex 5, France

* Corresponding author : Mohamed Nejib Daly Yahia, email address : nejibdaly@qu.edu.qa

\begin{abstract}
:
Copepods are excellent bioindicators of climate change and ecosystem pollution in anthropized coastal waters. This work reviewed the results of previous studies examining changes in egg production rate (EPR), hatching success (HS), and nauplius survival rate (NSR) in natural conditions and in the presence of pollutants, including heavy metals and organic contaminants such as polycyclic aromatic hydrocarbons (PAHs) and persistent organic pollutants (POPs). At high concentrations, cadmium and silver induce an increase in EPR in the copepods Acartia tonsa and Acartia hudsonica, while exposure to mercury decreases EPR in adults by $50 \%$. All three metals affect HS, with mercury inducing a stronger effect than cadmium and silver. Cadmium affects reproductive traits in Centropages ponticus, decreasing EPR and particularly HS. Furthermore, copper and chromium at high concentrations induce significant decreases in eggs per female in Notodiaptomus conifer. In terms of organic contaminant and Polycyclic Aromatic Hydrocarbons (PAHs), Eurytemora affinis is reported to be affected by naphthalene, 2methylnaphthalene, 2,6-dimethylnaphthalene, and 2,3,5-trimethylnaphthalene and can thus be used in ecotoxicity studies, but only if the exposure time is high. Acartia tonsa shows significant reductions in EPR and HS at high concentrations of fluoranthene, phenanthrene, and pyrene. However, the response to Persistent Organic Pollutants (POPs) such as pentachlorophenol (PCP) and 1,2-dichlorobenzene (DCB) differs. In E. affinis, EPR increases with $\mathrm{DCB}$, but $\mathrm{HS}$ falls to $<1 \%$. EPR increases when the species is exposed overnight, but HS remains low in the presence of DCB. Based on these results, we developed a novel copepod reproductive trait index (CRT-Index) for use in marine ecotoxicology surveys and tested in some simple cases. We show that copepods are good candidates as models for ecotoxicology studies, in particular using reproductive traits (EPR, HS and NSR) because of their sensitivity to a wide range or pollutants.
\end{abstract}

Keywords : Planktonic Copepods, Reproductive Traits, Ecotoxicology 


\section{Introduction}

Plankton are a useful indicator of marine ecosystem health status due to their significant role in the functioning of marine ecosystems and biogeochemical cycles, owing to their key position at the food web base and rapid response to environmental change (Kadiene et al., 2019). 
Planktonic copepods are a key component in aquatic food webs, acting as the main grazers of small autotrophic and heterotrophic nanoplankton and microplankton species, and as food sources for higher trophic levels (Cushing, 1990; Huys and Boxshall, 1991; Mauchline, 1998; Daly Yahia et al., 2004; Uye, 2011; Neffati et al., 2013). They also play a key role in the control of fish recruitment, since copepod eggs, nauplii, and copepodite stages are prey for larval and adult fish (Cushing, 1990; García and Palomera, 1996). Copepods can be excellent bioindicators of climate change and ecosystem shifts (Beaugrand, 2005) or of pollution in eutrophied coastal water areas ( Daly Yahia et al., 2004; Ben Lamine et al., 2015; Serranito et al., 2016; N'doua Etilé et al., 2017; Drira et al., 2018).

It has been shown that marine ecosystems react quickly to environmental modifications, particularly in coastal regions subjected to greater anthropogenic inputs (Beaugrand et al., 2010; Brander, 2010; Burrows et al., 2011) . Thus, in order to monitor these changes the term 'indicator' is applied in the EU Marine Strategy Framework Directive ( Borja et al., 2010; Rombouts et al., 2013). A set of bioindicators is an assessment and policy tool that enables a scenario or pattern to be measured, allowing ecosystem health and environment changes to be evaluated (Parmar et al., 2016), and ecosystem management to be improved (Niemi and McDonald, 2004). Zooplankton are prospective bioindicators for aquatic ecosystems, but are seldom considered in monitoring initiatives (Perry et al., 2004; Tett et al., 2008; Rombouts et al., 2013). They are reported to be sentinels of environmental modifications and pressures (Legendre and Rivkin, 2005; Richardson, 2008; Beaugrand et al., 2010). Through their role in carbon export to ocean depths and nutrient recycling to the lower productive layers, zooplankton create a connection between primary producers and higher trophic components (Banse, 1995; Urabe et al., 2002; Lankov, 2010). Zooplankton are also a source of nutrition for planktivorous fish larvae 
and carnivorous animals such as chaetognaths (Reiss et al., 2005). Among the zooplankton, copepods are the main species and likely also the most common multicellular organisms on Earth (Huys and Boxshall, 1991; Mauchline, 1998; Uye, 2011). The zooplankton assemblies of many Arctic and temperate marine environments, such as the North Atlantic, are dominated by calanoid copepods ( Mauchline, 1998; Beaugrand et al., 2002a,b). Copepods are commonly used in toxicity tests, as they are adaptable to the laboratory cultivation conditions, sensitive to toxicants, and of ecological relevance (Kulkarni et al., 2013; Anderson and Phillips, 2016; Kadiene et al., 2017; Kadiene et al., 2019).

Classical testing for toxicity in copepods mainly consists of acute and chronic tests examining the effect on actions of individuals, immune and endocrine processes, development, growth, and reproduction (Chen et al., 2011; Michalec et al., 2013; Kadiene et al., 2017). These tests may also examine mortality, EC50 (half maximum effective concentration), LC50 (half lethal concentration), and NOEC (no observable effect concentration). Different review papers have sought to generalize the use of animal groups, classes, or species as tools or environmental indicators. For example, Ferdous and Muktadir (2009) considered use of freshwater zooplankton and Kulkarni et al. (2013) use of copepods in freshwater ecotoxicology, while Hagerbaumer et al. (2015) reviewed use of nematodes in general ecotoxicology and Cornelis et al. (2018) use of terrestrial isopods as a model organism in soil ecotoxicology.

The aim of the present review was to assess copepod species as environmental bioindicators, based on the effect of heavy metal contaminants and of organic contaminants such as polycyclic aromatic hydrocarbons (PAHs) and persistent organic pollutants (POPs) on the reproductive traits of calanoid copepods. Changes in egg production rate (EPR), egg hatching success (HS), and nauplius survival rate (NSR) in copepods subjected to toxic conditions in various studies 
were compared and summarized, in order to identify useful copepod species for toxicity investigations. We then used the results to develop a new index based on copepod fertility (Copepod Egg Production Index (CEP-Index) or Copepod Reproductive Trait Index (CRTIndex)), to be used in aquatic ecotoxicology for assessing pollution impacts and environmental changes (Souissi et al., 2008; Annabi-Trabelsi and Daly Yahia, 2009; Neffati et al., 2013).

\section{Importance of copepods in marine and aquatic ecosystems}

In pelagic food webs, marine zooplankton comprise an assembly of metazoan consumers occupying various phylogenetic and functional trophic levels (Steinberg and Landry, 2017). Zooplankton provide important connections between primary producers and higher trophic levels, are essential ecosystem change markers, and play a crucial role in nutrient and carbon cycling (Kitchell et al., 1987; Pace et al., 2004). Alterations in zooplankton abundance and community structure may therefore have significant consequences for processes at the ecosystem level, as well as trophic cascades and water quality (Doubek et al., 2019).

Copepods are the most extensive metazoan subclass on Earth and generally dominate mesozooplankton, accounting for over 80\% of its biomass (Verity and Smetacek 1996). Copepods are crucial component in the diet of sea fish larvae (Santhanam et al., 2012), typically accounting for more than $50 \%$ of larval fish gut contents (Stottrup, 2000). It is well established that several marine fish larvae are unable to survive on typical live commercial feeds such as the rotifers Brachionus sp. and Artemia sp., thus posing great challenges in aquaculture production (McKinnon et al., 2003; O’Bryen and Lee, 2005; Chesney, 2005). These species include many highly cherished fish such as snappers (Lutjanidae) and groupers (Serranidae). Copepods have 13 distinguishable stages of life (egg, six naupliar stages, and six copepodid stages, including the 
adult stage), making it easy to monitor development, and many species are sexually dimorphic (Kwok et al. 2005). These features of the copepod life cycle and their significance in the aquatic food web make copepods an appropriate candidate for use in ecotoxicology studies (Kwok et al., 2015).

Copepods are important for the success of marine fish larvae, by providing them with live prey and acting as a dietary supplement to maximize fish survival and growth rate (Holt, 2003). Copepods, particularly calanoid and harpacticoids, are regarded as the most essential natural prey for marine fish larvae, because they not only contain nutrients that support fish larvae requirements and development, but are also capable of producing and inducing stimulatory appetitive effects on larvae and optimizing production of digestive enzymes (Olivotto et al., 2011; Zaleha et al., 2012). Rotifers and Artemia have advantages due to their suitability for larviculture (breeding and farming of fish larvae), easing mass production and increasing productivity and profitability. However, they are not as efficient dietary components as copepods, because of issues such as low feeding response in larvae with small mouths due to their size and because their nutritional composition, such as content of free amino acids and essential fatty acids, is not sufficient to sustain marine fish larvae (Ostrowski and Laidley., 2001). Use of copepods in commercial feeds for fish larvae is currently very limited, mainly due to its challenges and difficulties in their intensive culture (Alajmi and Zeng, 2015). However, with recent advances in culture techniques (Alajmi and Zeng, 2015), copepods may be used more widely in marine larviculture, especially for fish species that produce small number of larvae per spawning, such as marine ornamental fish. 


\section{Copepod reproductive traits}

Semelparity and iteroparity are possible reproductive strategies in living organisms (Begon et al., 1990). A species is regarded as semelparous if it is defined by a single pre-death reproductive episode, or iteroparous if it is defined by numerous reproductive cycles during its lifetime. In the case of many copepods, iteroparity in the adult stage consists of producing several clutches of eggs per reproductive cycle, i.e., they are iteroparous annuals according to Begon et al. (1990).

Measuring EPR has become a widely used method in ecological studies on copepods (Ianora et al., 2007). Egg HS and NSR are widely used in ecological studies too, but are also critical in ecotoxicology studies (Souissi et al., 2008; Neffati et al., 2013; Cherif et al., 2015). The reproductive biology of copepods depend on the quantity and quality of ingested food and abiotic factors such as temperature, turbidity, and pH (Miralto et al., 1999; Turner, 2004; Ianora et al., 2007).

In general, copepods might be suitable as relevant indicators in ecotoxicological studies, as they are sensitive to a range of pesticides and insecticides (Forget et al., 1998). Some studies have shown that the early developmental stages in copepods are particularly sensitive to contaminants and chemicals, which stresses the importance of considering their reproductive traits (EPR, HS, and NSR) (Kulkarni et al., 2013).

\subsection{Natural factors}

Various environmental conditions affect the reproductive biology of planktonic copepods. Egg production is affected by temperature (Devreker et al., 2009) and by the quality and amount of the available food (Kleppel et al. 1998). Salinity variations also affect the reproductive success of estuarine copepod species (Castro-Longoria, 2003). Devreker et al. (2009) observed high 
reproductive production of Eurytemora affinis in the Seine estuary in France, with intermediate and low salinities (between 5 and $15 \mathrm{ppt}$ ) tending to be ideal. Turbidity, especially in estuarine waters, is recognized to be another key limitation affecting copepod reproduction. Burdloff et al. (2000) demonstrated that increased levels of suspended particulate matter are responsible for poor nutritional quality in high-turbidity areas of the Gironde estuary in France, leading to low EPR in E. affinis. Additionally, photoperiod has a major influence on copepod reproduction. A study by Camus and Zeng (2008) showed a trend for increased EPR and hatching success with longer photoperiod, with the fastest mean growth times from egg to adult being correlated with extended illumination period.

Many studies have been carried out in efforts to understand the connections between copepod reproduction and ingested phytoplankton species, Research in the field and the laboratory has demonstrated a strong link between reproductive traits (fecundity, hatching success, naupliar survival) and food quantity, but also other features of foods such as size, morphology, taxonomic composition, toxicity, biochemical composition and bioactives compounds (Kleppel, 1995; Ban et al., 1997; Miralto et al.,1999; Laabir et al.,2001; Bonnet and Carlotti 2001; Ceballos and Ianora, 2003; Koski et al., 2006).

Among these studies, research conducted in the North Lagoon in Tunisia examined the effect of temperature and nutritional availability on seasonal fluctuations in EPR of one member of the Centropagiidae (Centropages kroyeri) and three Acartiidae copepods (Acartia clausi, Paracartia latisetosa, and Paracartia grani) (Annabi-Trabelsi and Daly Yahia, 2005; Annabi-Trabelsi et al., 2012). All three species of Acartiidae showed marked differences in EPR in response to season. The fertility of $P$. latisetosa and $P$. grani fertility was positively affected by temperature and salinity, while that of A. clausi fecundity was negatively affected, even though its EPR was 
supported by consumption of phytoplankton (chlorophyll- $a$ and sestonic proteins used as proxies). The EPR of the other two species was enhanced by particulate organic matter (POC), signifying that these species feed on micro-zooplankton and detritus rather than on phytoplankton (Annabi-Trabelsi et al., 2012). Comparable findings have been reported for temperate regions, where A. clausi usually occurs during cold-temperate periods, decreasing to relatively low population numbers or vanishing totally during summer. For example, in Japanese coastal waters, A. clausi vanishes from the water column at temperatures above $21^{\circ} \mathrm{C}$, with the eggs produced resting during summer (Uye, 1985). The EPR data in the literature generally indicate that $P$. latisetosa has the highest and most successful reproduction population traits in summer, P. grani in autumn, and A. clausi in winter (Annabi-Trabelsi et al., 2012). This demonstrates that there is an optimal range of temperature for egg production in different copepod species.

In order to compare differences between the natural EPR in copepods and the EPR value under the impact of contaminant, data on the EPR of various copepod species taken from different studies were compiled and are shown in Table 1. Comparisons indicate how the toxicity of the water affects the reproductive traits in two main genera, Acartia and Temora. In particular, Table 1 shows the range of ambient temperature in which the species is observed, the EPR (number of eggs female ${ }^{-1}$ day $^{-1}$ ), and study areas for various species of Acartia and Temora.

In a study to assess the impact of natural influences on copepod reproduction traits (Neffati et al., 2013), in autumn 2006 the EPR, HS, and NSR of the copepods Centropages ponticus, a lagoon species, and Temora stylifera, a marine species, were studied in the Bizerte channel off Tunisia based on their abiotic factors and phytoplankton composition (Table 1). The results revealed that the EPR and HS of $C$. ponticus remained moderately stable throughout autumn and were able to 
tolerate high turbidity, with mean EPR of $13.7 \pm 0.3$ eggs day $^{-1}$ and mean HS of $24.4 \pm 1.6 \%$, while the reproductive traits of $T$. stylifera fluctuated substantially, with mean EPR of $35.2+3.8$ eggs day $^{-1}$ and mean HS of $50.4+5.5 \%$. Thus due to its more offshore marine nature, T. stylifera could not withstand high coastal turbidity and hence had low EPR and HS under these conditions. In both species, changes in EPR and HS were as a consequence of natural environmental differences, especially maternal food availability in the form of phytoplankton composition, with a minimal observable decrease in EPR and HS after a major phytoplankton bloom. The NSR of C. ponticus was found to be closely quite related to temperature, while that of $T$. stylifera seemed to more sensitive to maternal food consumption (Neffati et al., 2013). According to Souissi et al. (2008), who conducted an experiment on Centropages kroyeri in the same region (Bizerte coastal zone), temperature generally plays a major role in controlling copepod reproduction and life cycle strategy, but the quality and quantity of food available also greatly influence reproduction.

\subsection{Toxicity affecting reproductive traits}

Toxicity tests are critical for biomonitoring and environmental risk assessment of released chemical substances. Good availability of procedures for the cultivation of organisms and bioassays using species reflecting changes at diverse trophic levels and for diverse taxonomic groups are essential for collecting data about the likely significance of environmental pollution (Gorbi et al., 2012). Improvements in calibration and emerging new standardized bioassay guidelines for species of ecological relevance are therefore of major importance in ecotoxicology (Raisuddin et al., 2007). Acute and chronic tests have shown sensitivity of copepods to various toxic substances, such as metals, antibiotics, insecticides, antifouling products, and surfactants (Sosnowski and Gentile, 1978; Gorbi et al., 2012). As a proxy method for approximating 
secondary pelagic production, measuring EPR and HS of adult female copepods has been proposed as a measure of potential population recruitment rates (Turner, 2004; Neffati et al., 2013). In addition, egg production is an important element of copepod adult biology, integrating a number of metabolic processes and thus having high ecological significance (Laabir et al., 1995; Souissi et al., 2008). Egg production and hatching in copepods has thus been shown to be a highly sensitive biological response to many toxicants, such as heavy metals, pesticides, PAHs, and testosterone ( Willis and Ling 2004; Bellas, 2007; Almeda, et al., 2014).

\section{Response to heavy metal contamination}

Heavy metals are considered to be among the most damaging aquatic pollutants (Verriopoulos, and Moraïtou-Apostolopoulou 1982). Their effects on aquatic organisms are extensive, as demonstrated predominantly in industrial pollution studies (Gutierrez et al., 2010). By assimilating metals from food or by absorbing them from water, copepods accumulate metals (Wang and Fisher 1998; Reinfelder et al., 1998), with the relative importance of the uptake pathway varying considerably between metals. The absorption path of a metal can determine its internal distribution (Hare, 1991; Wang and Fisher 1998), but few studies have assessed the toxicity of elements primarily absorbed from copepod food. Furthermore, there are very few studies on the effect of toxic metals in marine zooplankton (Sunda et al., 1987; Hook, 2001). Copper and chromium are critical heavy metals because they are key elements in metabolic processes, but become toxic at high levels (Sullivan et al., 1983; Sunda et al., 1987; Walker, 1990; Gorbi et al., 2012). Studies have shown that, as a result of human activities, the lower Salado River basin, one of Argentina's most crucial basins, is highly polluted with copper and chromium (Ceresoli and Gagneten 2003; Gagneten, 2007, 2009). Copper is used commercially 
as an algaecide in antifouling paint and also in fish disease treatment (Gutierrez et al., 2010).

Chromium is used in a variety of industries, as a leather tanning agent, in stainless steel electroplating, and in glass, pigment, fungicide, and battery production.

Table 2 shows the EPR of various species of calanoid copepods under different concentrations of copper and chromium in two different studies. In mixed culture of Acartia and Paracalanus spp. in the Saanich Inlet, British Columbia, it was found that, as eggs matured, their reproduction, survival, and HS decreased even without the interference of any heavy metals (Reeve et al., 1977). However, as the concentration of copper input increased, egg production decreased more rapidly and at $100 \mu \mathrm{g} \mathrm{L}^{-1}$ there was no recorded egg production at all (Reeve et al., 1977) (Table 2). This means that when algaecides and fish disease chemicals are used in large quantities without regulatory control, there is less reproduction of copepods and their population can decline in polluted areas ( Reeve et al., 1977). In contrast, the copepod Notodiaptomus conifer showed rather different reproductive behavior in the presence of copper in experimental tanks in a study by Gutierrez et al. (2010). In the absence of copper, each female produced a mean of 5.67 eggs, while at a copper concentration of $0.4 \mu g \mathrm{~L}^{-1}$ each female produced a mean of 7 eggs, which increased to a mean egg count of 11.2 when the copper concentration increased to $0.8 \mu \mathrm{g} \mathrm{L}^{-1}$. However, upon doubling the copper concentration again, to $1.6 \mu \mathrm{g} \mathrm{L}^{-1}$, the mean number of eggs produced per female dropped to 7.5. There was no egg production at all when the concentration of copper increased to $3 \mu \mathrm{g} \mathrm{L}^{-1}$ (Gutierrez et al., 2010). This shows that there is an optimal level of egg reproduction in female copepods in the presence of copper, since it is an essential element for metabolic processes, but with lethal effects above a threshold concentration. In the same study, chromium, which is also important for metabolic processes, gave a rapid decrease in mean number of eggs produced per female (from 9.66 to 3 ) 
when the concentration was increased from 0 to $7.5 \mu \mathrm{g} \mathrm{L}^{-1}$, but no egg production at all at concentrations of 15 and $30 \mu \mathrm{g} \mathrm{L}^{-1}$ (Gutierrez et al., 2010). Thus, in general, depending on the sampling location or different pelagic areas or inland waters, copepods appear to thrive better in the absence of chromium, but female copepods need a certain amount of copper for metabolic processes, egg reproduction, and hatching success (Table 2).

Exposure of Centropages ponticus in the Bizerte Lagoon, Tunisia, to cadmium at $18^{\circ} \mathrm{C}$ resulted in an inverse relationship between cadmium concentration and both EPR and HS (Cherif et al., 2015). With exposure to cadmium at $0.2 \mu \mathrm{g} \mathrm{L}^{-1}$, EPR and HS declined from the value in the cadmium-free control (set at $100 \%$ ) to $57.75 \%$ and $59.64 \%$, respectively, but most of the eggs produced hatched successfully. At a cadmium concentration of $1 \mu \mathrm{g} \mathrm{L}^{-1}$, EPR declined drastically to $22.52 \%$ and HS to $13.09 \%$ compared with the control (Cherif et al., 2015).

In a study at Stony Brook Harbor in the USA (Hook and Fisher 2001), the copepods Acartia tonsa and A. hudsonica were exposed to mercury, cadmium, and silver at a temperature range of $15-25{ }^{\circ} \mathrm{C}$ (Table 3). The heavy metals were applied at five concentrations ( 0 (control), $0.25,0.5$, 1, and $2 \mathrm{nM}$. For mercury, the control group showed $100 \pm 10 \%$ EPR and $100 \pm 15 \%$ HS, but at $0.25 \mathrm{nM}$ both the EPR and HS nearly halved, to $52 \pm 7 \%$ and $57 \pm 5 \%$, respectively. However, EPR did not change significantly on increasing the mercury concentration to $2 \mathrm{nM}$. The HS was barely affected at 0.5 and $2 \mathrm{nM}$, but the highest $\mathrm{HS}(110 \%)$ was observed at $0.5 \mathrm{nM}$ and the lowest HS at $1 \mathrm{nM}$. This shows that even small changes in the concentration of mercury can reduce the EPR and HS by up to 50\% (Table 3). In contrast, for cadmium the EPR of $100 \pm 14 \%$ and HS of $100 \pm 18 \%$ in the control decreased only slightly as the concentration increased to $0.25 \mathrm{nM}$, resulting in EPR of $89 \pm 10 \%$ and HS of $85 \pm 8 \%$. The EPR then increased to $115 \pm$ $20 \%$ as the concentration of cadmium increased to $2 \mathrm{nM}$, i.e., higher than in the control, while 
HS showed a consistent decrease as the concentration of cadmium increased (Table 3). Similarly, silver gave an increase in EPR as the concentration increased to $2 \mathrm{nM}$, although with a small decline in EPR at $0.25 \mathrm{nM}$. This indicates that cadmium and silver concentrations of up to $2 \mathrm{nM}$ may increase EPR, but that cadmium may affect HS (Table 3).

\section{Response to organic contaminants (PAHs)}

Polycyclic aromatic hydrocarbons are persistent planar molecules comprised of two or several six-member (benzene) rings directly connected together, and are commonly found in aquatic ecosystems (Kennish, 1992; Walker et al., 2004). Main sources of PAHs industrial waste products, oil spills, and fossil fuel refining and combustion (Walker et al., 2004; Albers, 2002; Fourati et al., 2018). Worldwide, PAH discharges from all natural and anthropogenic sources into aquatic environments are reported to be 80,000-230,000 tons per year (Kennish, 1992; Wright and Welbourn, 2002; Soliman et al., 2014, 2019). PAHs are by far the most deadly components of oil for maritime biota, with genotoxic, carcinogenic, and reproductive effects, and can bioaccumulate in maritime species (Corner et al., 1976; Kennish, 1992; Albers, 2002; Pane et al., 2005; Manahan, 2010). Although low molecular weight PAHs are the most toxic, they are generally unimportant in ecological terms due to their volatility and consequently short half-life in water (Walker et al., 2004).

Investigations by Ott et al. (1978) showed that $E$. affinis can be used in ecotoxicity studies testing long exposure time to naphthalene, 2-methylnaphthalene, 2,6-dimethylnaphthalene, and 2,3,5trimethylnaphthalene (Table 5). A study by Bellas and Thor (2007) examined A. tonsa females exposed to different concentrations of fluoranthene, phenanthrene, and pyrene, to determine their effect on EPR and HS. At a concentration of $10 \mathrm{nM}$, fluoranthene did not have any effect on 
EPR, at concentrations up to $50 \mathrm{nM}$ it showed a consistent decrease in EPR, at $250 \mathrm{nM}$ the EPR increased slightly, while at higher concentrations there was a sudden decrease in EPR. A significant difference $(\mathrm{p}<0.001)$ was observed at 800 and $1250 \mathrm{nM}$ (Bellas and Thor, 2007). A similar correlation was observed for pyrene, but at different concentrations. Relative to the control, EPR slightly increased as the pyrene concentration increased up to $160 \mathrm{nM}$, but a sudden decrease in EPR was observed at concentration $\geq 320 \mathrm{nM}$. For phenanthrene, the results showed a slight decrease in EPR in lower concentrations, an increase from $24 \mathrm{nM}$ to $600 \mathrm{nM}$, and a sudden decrease in EPR at concentrations greater than $1800 \mathrm{nM}$ (Bellas and Thor, 2007). In terms of detrimental effects on EPR, concentrations greater than $400 \mathrm{nM}$ fluoranthene, $320 \mathrm{nM}$ pyrene, and $1800 \mathrm{nM}$ phenanthrene appear to be critical (Table 5).

The same study examined changes in egg HS with increasing concentrations of the same three PAHs. For fluoranthene, HS decreased slightly at a concentration of $10 \mathrm{nM}$, increased slightly until $200 \mathrm{nM}$, and then decreased steadily until $1250 \mathrm{nM}$ (Bellas and Thor, 2007). A similar pattern was observed for pyrene, but at different concentrations, e.g., at concentrations of 320 and $640 \mathrm{nM}$ HS remained the same. In the case of phenanthrene, higher HS compared with the control was observed at 2, 4, and $240 \mathrm{nM}$, and then a steady decrease was observed at higher concentrations (Bellas and Thor, 2007).

\section{Response to other persistent organic pollutants}

The effect of organochlorine complexes on HS of calanoid copepods was examined in a study on E. affinis and A. bifilosa by Lindley et al. (1999) using pentachlorophenol (PCP) and 1,2-dichlorobenzene (DCB). PCP is a widely utilized biocide, on the Red List of primacy contaminants, but not the EEC and US EPA priority lists (Lindley et al., 1999). It has been 
detected in large volumes in freshwater sediments in the USA (Hoke et al., 1993) and throughout the Scheldt estuary, the Netherlands (Vanzoest and Vaneck 1991). In non-ionized form, it is very hydrophobic and can easily be immersed in deposits and bioaccumulated in mitochondria, where it hampers respiration (Mahler and Cordes, 1968).

In the study by Lindley et al. (1999), samples of eggs were subjected to various treatments, while one control group of eggs was incubated in filtered sea water (FSW) throughout and another control group was kept under FSW overnight (Table 5). The sea water for FSW was collected from the Eddystone Rocks in the English Channel. The number of E. affinis eggs produced was found to be significantly higher in DCB solution compared with the control group, but HS was less than $1 \%$ of that in the control, in which more than $99 \%$ of eggs hatched. Similarly, the number of eggs produced by E. affinis in DCB overnight was higher than in the corresponding control, but HS was lower, only $36 \pm 53 \%$, compared with $100 \%$ in the control group (Lindley et al., 1999). When A. bifilosa fecundity was tested in PCP solution, the results showed that the number of eggs produced was similar to that in the control, but HS for the sample exposed to PCP was zero. Exposure overnight gave higher egg production in the PCP sample, but HS was still zero (Lindley et al., 1999). This shows that egg production in these copepod species can tolerate POP-contaminated waters, but the hatching rate of eggs appears to be quite sensitive to DCB and PCP (Table 6).

\section{Discussion}

This review examined the significance of planktonic copepod reproductive traits as ecological indicators and their prospective significance in ecotoxicology. In the literature reviewed, various 
species of calanoid copepods were identified to be affected by heavy metals, organic contaminants, and POPs. The effects were measured by observing changes in EPR, HS, and NSR. Based on the reported changes, we suggest expanding the concept of using copepods as a model for copepod reproductive characteristics or traits in aquatic ecotoxicology by applying a "Copepod Egg Production Rate Index" and a more specific "Copepod Reproductive Trait Index" in marine and environmental tracking and pollution surveys.

In terms of heavy metals, various studies show that heavy metals such as copper, chromium, mercury, and silver induce a decrease in EPR and HS as the concentration of the contaminant increases. However, in the case of cadmium and silver the changes are not consistent, e.g., for cadmium the EPR and HS may increase with concentration up to a certain threshold (Hook and Fisher, 2001). For silver, HS may be unaffected, e.g., the copepod species $A$. tonsa and $A$. hudsonica incubated with concentrations of $1 \mathrm{nM}$ and $2 \mathrm{nM}$ silver showed $\mathrm{HS}$ of $79 \%$ and $96 \%$, respectively. This indicates that $A$. tonsa and A. hudsonica are not suitable species to be used in ecotoxicology studies examining pollution by cadmium and silver. However, these two species can be used in ecotoxicology studies for mercury, due to a clear correlation of decreasing EPR and HS as the mercury concentration increases (Hook and Fisher, 2001). A factor affecting the results may be a high concentration of mercury in relation to cadmium and silver.

In studies of cadmium toxicity, $C$. ponticus appears to be the best candidate copepod species, due to decreasing EPR and HS as the concentration of cadmium increases (Cherif et al., 2015). Furthermore, $N$. conifer can be used to assess copper and chromium toxicity, since the number of eggs per female drops as the concentration of copper and chromium increase (Gutierrez, 2010). In copper toxicity studies, a mixed culture of Acartia and Paracalanus could be used, since the EPR in both decreases rapidly as the copper concentration and number of days of exposure 
increase (Reeve et al., 1977).

The response of $E$. affinis to the organic contaminant naphthalene in terms of EPR changes is not significant at low concentrations and an exposure time of 10 days. However, at high concentrations and exposure time of less than 29 days, Ott et al., (1978) observed a reduction of 43.7\% in EPR. Furthermore, when exposed for less than 29 days to PAHs (2-methylnaphthalene, 2,6-dimethylnaphthalene and 2,3,5-trimethylnaphthalene) E. affinis suffered a significant reduction in EPR (Ott et al., 1978). When fluoranthene was tested with Tisbe battagliai, an harpacticoid copepod, there was reduction in clutch size of $50 \%$ at a concentration of $66.9 \mu \mathrm{g} . \mathrm{L}^{-1}$ in only 6 days of exposure time (Barata, 2002).

Belas and Thor (2007) found that EPR in A. tonsa significantly decreased at concentrations $\geq 50$ $\mathrm{nM}$ of fluoranthene, $\geq 1800 \mathrm{nM}$ of phenanthrene, and $\geq 320 \mathrm{nM}$ of pyrene. Eggs from the same species only showed a significant reduction in HS in fluoranthene, although phenanthrene and pyrene caused a slight decrease (Bellas and Thor, 2007).

Persistent organic pollutants such as PCP and DCB have been shown to have effects on EPR and HS in E. affinis and A. bifilosa. Compared with control groups, the number of eggs produced in the presence of DCB is reported to be significantly higher, but HS is reduced by $99 \%$ (Lindley et al., 1999). In that study, the amount of eggs generated by E. affinis in the presence of DCB overnight was greater than in the control, but HS was only $36 \pm 53 \%$, compared with $100 \%$ in the control (Lindley et al., 1999). Thus for E. affinis, evaluating HS is more suitable than EPR to detect any effect of DCB.

In the study by Lindley et al. (1999), A. bifilosa in the presence of PCP produced the same number of eggs as in the control, but hatching performance was zero. While the PCP sample 
showed higher production of eggs in a similar approach, but kept overnight, HS was still zero. This shows that production of eggs in contaminated waters may be higher, but that hatching is disrupted by both DCB and PCP.

Based on this review, copepod reproductive traits can be used in ecotoxicology studies to evaluate the impact of different contaminants. We developed a new index using planktonic copepods as a model for copepod reproductive traits or characteristics in aquatic ecotoxicology: the "Copepod Reproductive Trait Index" (CRT-Index):

$$
\text { CRT }- \text { INDEX }=\frac{\text { EPRS }+ \text { HS }+ \text { NSR }(24 h)+\text { NSR }(48 \mathrm{~h})}{4}
$$

where EPRS is female copepod egg production rate success, HS is egg hatching success, and NSR (24h) and NSR (48h) is nauplius survival rate after $24 \mathrm{~h}$ and $48 \mathrm{~h}$, respectively, and:

$$
\begin{aligned}
& \text { EPRS }=\frac{\text { Number of eggs produced per spawning female } / \text { day }}{\text { Number of eggs produced per spawning female } / \text { day in pristine conditions }} \times 100 \\
& \boldsymbol{H S}=\frac{\text { Total number of nauplii hatched }}{\text { All resulting eggs }} \times 100 \\
& \boldsymbol{N S R}(\mathbf{2 4} / \mathbf{4 8} \boldsymbol{h})=\frac{\text { Total number of nauplii surviving after } \frac{24}{48} \mathrm{~h}}{\text { All nauplii hatched }} \times 100
\end{aligned}
$$

We propose the following classification of environment or pollutant impact levels based on the CRT-Index applied to copepod reproductive traits, using data produced by Neffati et al. (2013) as an example. Figures 1 and 2 show, respectively, weekly changes in CRT-Index in the Bizerte Channel, Tunisia, from November 18 to December 8, 2006.

For Temora stylifera, which is a more neritic species with well-established populations in the Bay of Bizerte, the CRT-Index ranged from 0\% to $67.02 \%$. Based on this species, the Bizerte 
Channel shows in general a medium to high contamination status or environmental impact. For Centropages ponticus, a more coastal and lagoon species with well-established populations in the Bizerte Lagoon, the CRT-Index values are lower and range from $10.22 \%$ to $31.92 \%$, indicating high to very high contamination status in the Bizerte Channel.

This example demonstrates the utility of our novel index for coastal ecotoxicology and the more sensitive coastal species to contamination and environmental impacts. In this case, Centropages ponticus appears more sensitive to coastal and lagoon perturbations with less pronounced index fluctuations compared with Temora stylifera.

\section{8- Conclusions}

Based on a review of the literature, we show that reproductive traits in planktonic copepods are good biological indicators of coastal environmental status and ecosystem pollution in entropized coastal waters. Thus planktonic copepods are good candidates as models for ecotoxicology studies, in particular using reproductive traits such as daily egg production rate (EPR), egg hatching success (HS), and nauplius survival rate (NSR) after $24 \mathrm{~h}$ and $48 \mathrm{~h}$ of incubation. In all published papers dealing with planktonic copepod reproductive traits, one or more reproductive parameters of various species of copepods were identified as being affected by different contaminants, including persistent organic pollutants. Copepod responses to these pollutants were measurable as general reductions in EPR, HS, and NSR.

Based on the literature, we propose a new tool for use in aquatic ecotoxicology: Copepod Reproductive Trait Index (CRT-Index), based on the reproductive traits EPRS, HS, and NSR after 24 and $48 \mathrm{~h}$, for coastal environment monitoring and pollution status surveys. A simple 
example based on two contrasting calanoid copepod species, Temora stylifera and Centropages ponticus, in the south-western Mediterranean Sea, illustrates the utility of this new tool in classifying coastal and lagoon waters in terms of contamination or environmental impact status.

Natural planktonic copepod populations such as calanoid copepod neritic species can easily be reared in the laboratory and used to evaluate coastal environmental status using CRT-Index. This ecotoxicology tool could be implemented in coastal monitoring programs within the framework of Integrated Coastal Zones Management.

\section{References}

Alajmi, F., Zeng, C., 2015. Evaluation of microalgal diets for the intensive cultivation of the tropical calanoid copepod, Parvocalanus crassirostris. Aquac. Res. 46 (5), 1025-1038. https://doi.org/10.1111/are.12254

Albers, P., 2003. Petroleum and individual polycyclic aromatic hydrocarbons, in: Hoffman, D., Rattner, B., Burton, G.A., Cairns, J., (Eds.), Handbook of Ecotoxicology. CRC Press Company, New York, pp. 341-371. https://doi.org/10.1201/9781420032505.ch14.

Almeda, R., Baca, S., Hyatt, C., Buskey, E.J., 2014. Ingestion and sublethal effects of physically and chemically dispersed crude oil on marine planktonic copepods. Ecotoxicology 23 (6), 988-1003. https://doi.org/10.1007/s10646-014-1242-6

Anderson, B., Phillips, B., 2016. Saltwater Toxicity Tests, in: Blasco, D.J., Chapman, P.M., Campana, O., Hampel, M. (Eds.) Marine Ecotoxicology, Current Knowledge and Future Issues. Academic Press, London, 334 pp. 167-197. https://doi.org/10.1016/B978-0-12803371-5.00006-0

Annabi-Trabelsi, N., Daly Yahia, M.N., Maïz, N., 2005. Seasonal variability of planktonic copepods in Tunis North Lagoon (Tunisia, North Africa). Cah. Biol. Mar. 46, 325-333.

Annabi-Trabelsi, N., Daly Yahia., M.N., Genuario, B., Aleya., L., Habib, A., 2012. Impacts of very warm temperature on egg production rates of three Acartiidae (Crustacea, Copepoda) in a Northern African lagoon. J. Therm. Biol. 37 (6), 445-453. https://doi.org/10.1016/j.jtherbio.2012.03.003

Annabi-Trabelsi, N., Daly-Yahia, M.N., 2009. Centropages kroyeri egg production rate as a 
function of lagoon summer conditions. Thalassia Salent. 32, 17-27.

Ban, S., Burns, C., Castel, J., Christou, E., Escribano, R., Umani, S. F., Gasparini, S., Ruiz F.,G., Hoffmeyer, M., Ianora, A., Kang, H., Laabir, M., Lacoste, A., Miralto, A., Poulet, S. A., Ning, X., Rodriguez, V., Runge, J., Shi, J., Starr, M., Uye, S., Wang, Y., 1997. The paradox of the classic marine food web. Mar. Ecol. Prog. Ser. 157, 287-293.

Banse, K., 1995. Zooplankton: pivotal role in the control of ocean production. ICES J. Mar. Sci. 52 (3-4), 265-277. https://doi.org/10.1016/1054-3139(95)80043-3

Beaugrand, G., Reid, P.C., Ibanez, F., Lindley, J.A., Edwards, M., 2002a. Reorganization of North Atlantic marine Copepod biodiversity and climate. Science 296, 1692-1694.

Beaugrand, G., Ibanez, F., Lindley, A.J., Reid, P.C., 2002b. Diversity of calanoid copepods in the North. Atlantic and adjacent seas: species associations and biogeography. Mar. Ecol. Prog. Ser. 232, 179-195.

Beaugrand, G., 2005. Monitoring pelagic ecosystems using plankton indicators. ICES J. Mar. Sci. 62 (3), 333-338. https://doi.org/10.1016/j.icesjms.2005.01.002

Beaugrand, G., Edwards, M., Legendre, L., 2010. Marine biodiversity, ecosystem functioning, and carbon cycles. Proc. Natl. Acad. Sci. 107 (22), 10120-10124. https://doi.org/10.1073/pnas.0913855107

Begon, M., Harper, J.L., Reynolds, C.R., 1990. Ecology. individuals, populations and communities, second ed., Blackwell Scientific Publications, Boston.

Bellas, J., Thor, P., 2007. Effects of selected PAHs on reproduction and survival of the calanoid copepod Acartia tonsa. Ecotoxicology 16 (6), 465-474. https://doi.org/10.1007/s10646007-0152-2

Ben Lamine, Y., Pringault, O., Aissi, M., Cherif, E., Mahmoudi, E., Kefi-Daly Yahia, O., Daly Yahia, M.N., 2015. Environmental controlling factors of copepod communities in the Gulf of Tunis (south western Mediterranean Sea). Cah. Biol. Mar. 56, 213-229.

Bonnet, D., Carlotti, F., 2001. Development and egg production in Centropages typicus (Copepoda: Calanoida) fed different food types: a laboratory study. Mar. Ecol. Prog. Ser. 224, 133-148. https://doi.org/10.3354/meps224133.

Borja, Á., Elliott, M., Carstensen, J., Heiskanen, A.-S., Van de Bund, W., 2010. Marine management - Towards an integrated implementation of the European marine strategy framework and the water framework directives. Mar. Pollut. Bull. 60 (12), 2175-2186. https://doi.org/10.1016/j.marpolbul.2010.09.026.

Brander, K., 2010. Impacts of climate change on fisheries. J. Marine Syst. 79 (3-4), 389-402. 
https://doi.org/10.1016/j.jmarsys.2008.12.015;

Burdloff, D., Gasparini, S., Sautour, B., Etcheber, H., Castel, J., 2000. Is the copepod egg production in a highly turbid estuary (the Gironde, France) a function of the biochemical composition of seston? Aquat. Ecol. 34 (2), 165-175. https://doi.org/10.1023/A:1009903702667.

Burrows, M.T., Schoeman, D.S., Buckley, L.B., Moore, P., Poloczanska, E.S., Brander, K.M., Brown, C., Bruno, J.F., Duarte, C.M., Halpern, B.S., Holding, J., Kappel C.V., Kiessling, W., O'Connor, M.I., Pandolfi, J.M., Parmesan, C., Schwing, F.B., Sydeman, W.J., Richardson, A.J., 2011. The pace of shifting climate in marine and terrestrial tcosystems. Science, 334 (6056), 652-655. https://doi.org/10.1126/science.1210288

Calbet, A., Saiz, E., Alcaraz, M., 2002. Copepod egg production in the NW Mediterranean: Effects of winter environmental conditions. Mar. Ecol. Prog. Ser. 237, 173-184. https://doi.org/10.3354/meps237173.

Camus, T., Zeng, C., 2008. Effects of photoperiod on egg production and hatching success, naupliar and copepodite development, adult sex ratio and life expectancy of the tropical calanoid copepod Acartia sinjiensis. Aquaculture 280 (1-4), 220-226. https://doi.org/10.1016/j.aquaculture.2008.05.008.

Camus, T., Zeng, C., \& McKinnon, A.D. (2009). Egg production, egg hatching success and population increase of the tropical paracalanid copepod, Bestiolina similis (Calanoida: Paracalanidae) fed different microalgal diets. Aquaculture 297 (1-4), 169-175. https://doi.org/10.1016/j.aquaculture.2009.09.018.

Carlotti, F., Rey, C., Javanshir, A., Nival, S., 1997. Laboratory studies on egg and faecal pellet production of Centropages typicus. Effect of age, effect of temperature, individual variability. J. Plankton Res. 19 (8), 1143-1165.

Castro-Longoria, E. (2003). Egg production and hatching success of four Acartia species under different temperature and salinity regimes. J. Crust. Biol. 23 (2), 289-299.

Ceballos, S., Ianora, A., 2003. Different diatoms induce contrasting effects on the reproductive success of the copepod Temora stylifera. J. Exp. Mar. Biol. Ecol. 294 (2), 189-202. https://doi.org/10.1016/S0022-0981(03)00263-6.

Ceresoli, N., Gagneten, A. M., 2003. Efectos del efluente de curtiembre sobre Ceriodaphnia dubia (crustacea, cladocera) en condiciones experimentales. Interciencia 28 (8), 469-475.

Chen, S., Zhou, R., Huang, Y., Zhang, M., Yang, G., Zhong, C., Shi, S., 2011. Transcriptome sequencing of a highly salt tolerant mangrove species Sonneratia alba using Illumina platform. Mar. Genomics 4 (2), 129-136. https://doi.org/10.1016/j.margen.2011.03.005. 
Cherif, E., Pringault, O., Hannaoui, W., Yahia, M.N.D., 2015. Effects of Cadmium Exposure on Reproduction and Survival of the Planktonic Copepod Centropages ponticus. J. Marine Sci. Res. Dev. 5, 159. https://doi.org/10.4172/2155-9910.1000159.

Chesney, E. J., 2005. Copepods as live prey: A review of factors that influence the feeding success of marine fish larvae, in: Lee, C.S., O’Bryen, P. J., Marcus, N.H. (Eds.), Copepods in Aquaculture, Blackwell Publishing, Iowa, pp. 133-150. https://doi.org/10.1002/9780470277522.ch11.

Corner, E.D.S., Harris, R.P., Kilvington, C.C., O’Hara, S.C.M., 1976. Petroleum compounds in the marine food web: Short-term experiments on the fate of naphthalene in Calanus. J. Mar. Biol. Assoc. U. K. 56 (1), 121-133. https://doi.org/10.1017/S0025315400020488.

Cushing, D.H., 1990. Plankton production and year-class strength in fish populations: An update of the match/mismatch hypothesis. Adv. Mar. Biol. 26, pp. 249-293. https://doi.org/10.1016/S0065-2881(08)60202-3.

Daly Yahia, M.N., Souissi, S., Kefi - Daly Yahia, O., 2004. Spatial and temporal structure of planktonic copepods in the Bay of Tunis (Southwestern Mediterranean Sea). Zool. Stud. $43,366-375$.

Devreker, D., Souissi, S., Winkler, G., Forget-Leray, J., Leboulenger, F., 2009. Effects of salinity, temperature and individual variability on the reproduction of Eurytemora affinis (Copepoda; Calanoida) from the Seine estuary: A laboratory study. J. Exp. Mar. Biol. Ecol. 368 (2), 113-123. https://doi.org/10.1016/j.jembe.2008.10.015.

Doubek, J.P., Carey, C.C., Lavender, M., Winegardner, A.K., Beaulieu, M., Kelly, Pollard, A.I., Straile, D., Stockwell, J.D., 2019. Calanoid copepod zooplankton density is positively associated with water residence time across the continental United States. PLoS One, 14(1), e0209567. https://doi.org/10.1371/journal.pone.0209567.

Drira, Z., Kmiha-Megdiche, S., Sahnoun, H., Tedetti, M., Pagano, M., Ayadi, H., 2018. Copepod assemblages as a bioindicator of environmental quality in three coastal areas under contrasted anthropogenic inputs (Gulf of Gabes, Tunisia). J. Mar. Biol. Assoc. U. K. 98 (8), 1889-1905. https://doi.org/10.1017/S0025315417001515.

Durbin, E.G., Durbin, A.G., Smayda, T.J., Verity, P.G., 1983. Food limitation of production by adult Acartia tonsa in Narragansett Bay, Rhode Island: Egg production in Acartia. Limnol. Oceanogr. 28 (6), 1199-1213. https://doi.org/10.4319/lo.1983.28.6.1199.

Ferdous, Z., Muktadir, A.K.M., 2009. A Review: potentiality of zooplankton as bioindicator. Am. J. Appl. Sci. 6 (10), 1815-1819. doi:10.3844/ajassp.2009.1815.1819.

Fourati, R., Tedetti, M., Guigue, C., Goutx, M., Zaghden, H., Sayadi, S., Elleuch, B., 2018. 
Natural and anthropogenic particulate-bound aliphatic and polycyclic aromatic hydrocarbons in surface waters of the Gulf of Gabès (Tunisia, southern Mediterranean Sea). Environ. Sci. Pollut. Res. Int. 25 (3), 2476-2494. https://doi.org/10.1007/s11356017-0641-7.

Forget, J., Pavillon, J. F., Menasria, M. R., Bocquené, G., 1998. Mortality and LC50 values for several stages of the marine Copepod Tigriopus brevicornis (Müller) exposed to the metals Arsenic and Cadmium and the pesticides Atrazine, Carbofuran, Dichlorvos, and Malathion. Ecotoxicol. Environ. Saf. 40 (3), 239-244. https://doi.org/10.1006/eesa.1998.1686.

Gagneten, A.M., Gervasio, S., Paggi, J.C., 2007. Heavy metal pollution and eutrophication in the lower Salado river basin (Argentina). Water Air Soil Pollut. 178 (1), 335-349. https://doi.org/10.1007/s11270-006-9202-2.

Gagneten, A.M., Plá, R.R., Regaldo, L., Paggi, J.C., 2009. Assessment of bioconcentration factor of Chromium by instrumental neutron activation analysis in Argyrodiaptomus falcifer Daday, a subtropical freshwater Copepod. Water Air Soil Pollut. 204 (1), 133-138. https://doi.org/10.1007/s11270-009-0032-x

García, A., Palomera, I., 1996. Anchovy early life history and its relation to its surrounding environment in the Western Mediterranean basin. Sci. Mar. 60 (2), 155-166.

Gorbi, G., Invidia, M., Savorelli, F., Faraponova, O., Giacco, E., Cigar, M., Buttino, I, Leoni, T, Prato, E, Lacchetti, I, Sei, S., 2012. Standardized methods for acute and semichronic toxicity tests with the copepod Acartia tonsa. Environ. Toxicol. Chem. 31 (9), 20232028. https://doi.org/10.1002/etc.1909.

Gutierrez, M.F., Gagneten, A.M., Paggi, J.C., 2010. Copper and Chromium alter life cycle variables and the equiproportional development of the freshwater copepod Notodiaptomus conifer (SARS). Water Air Soil Pollut. 213 (1-4), 275-286. https://doi.org/10.1007/s11270-010-0383-3.

Hagerbaumer, A., Hoss, S., Heininger, P., Traunspurger, W., 2015. Experimental studies with Nematodes in ecotoxicology: An overview. J. Nematol. 47 (1):11-27.

Halsband, C., Hirche, H., 2001. Reproductive cycles of dominant calanoid copepods in the North Sea. Mar. Ecol. Prog. Ser. 209, 219-229. https://doi.org/10.3354/meps209219.

Halsband-Lenk, C., 2001. Seasonal cycles of egg production of two planktonic copepods, Centropages typicus and Temora stylifera, in the North-western Mediterranean Sea. J. Plankton Res. 23 (6), 597-609. https://doi.org/10.1093/plankt/23.6.597.

Halsband-Lenk, Claudia, Carlotti, F., Greve, W., 2004. Life-history strategies of calanoid 
congeners under two different climate regimes: A comparison. ICES J. Mar. Sci. 61 (4), 709-720. https://doi.org/10.1016/j.icesjms.2004.03.020.

Halsband-Lenk, Claudia, Hirche, H.-J., Carlotti, F., 2002. Temperature impact on reproduction and development of congener copepod populations. J. Exp. Mar. Biol. Ecol. 271 (2), 121-153. https://doi.org/10.1016/S0022-0981(02)00025-4.

Hansen, F. C., Möllmann, C., Schütz, U., Neumann, T., 2006. Spatio-temporal distribution and production of calanoid copepods in the central Baltic Sea. J. Plankton Res. 28 (1), 39-54. https://doi.org/10.1093/plankt/fbi097.

Hare, L., Tessier, A., Campbell, P.G.C., 1991. Trace element distributions in aquatic insects: variations among genera, elements, and lakes. Can. J. Fish. Aquat. Sci. 48 (8), 14811491. https://doi.org/10.1139/f91-176.

Hoke, R.A., Giesy, J. P., Zabik, M., Unger, M., 1993. Toxicity of sediments and sediment pore waters from the grand Calumet River-Indiana Harbor, Indiana area of concern. Ecotoxicol. Environ. Saf. 26 (1), 86-112. https://doi.org/10.1006/eesa.1993.1042.

Holt, G. J., 2003. Research on culturing the early life stages of marine ornamental Fish, in: Cato, J.C., Brown, C.L. (Eds.), Marine Ornamental Species: Collection, Culture and Conservation. Iowa State Press, Iowa, pp. 249-254. https://doi.org/10.1002/9780470752722.ch17.

Hook, S.E., Fisher, N.S., 2001. Reproductive toxicity of metals in calanoid copepods. Mar. Biol. 138 (6), 1131-1140. https://doi.org/10.1007/s002270000533.

Huys, R., Boxshall, G.A., 1991. Copepod Evolution, Ray Society, London.

Ianora, A., Miralto, A., Halsband-Lenk, C., 2007. Reproduction, hatching success, and early naupliar survival in Centropages typicus. Prog. Oceanogr. 72 (2-3), 195-213. https://doi.org/10.1016/j.pocean.2007.01.009.

Kadiene, E.U., Bialais, C., Ouddane, B., Hwang, J.-S., Souissi, S., 2017. Differences in lethal response between male and female calanoid copepods and life cycle traits to cadmium toxicity. Ecotoxicology 26 (9), 1227-1239. https://doi.org/10.1007/s10646-017-1848-6.

Kadiene, E.U., Meng, P.-J., Hwang, J.-S., Souissi, S., 2019. Acute and chronic toxicity of cadmium on the copepod Pseudodiaptomus annandalei: A life history traits approach. Chemosphere, 233, 396-404. https://doi.org/10.1016/j.chemosphere.2019.05.220.

Kennish, M., 1992. Ecology of Estuaries: Anthropogenic Effects, first ed. CRC Press, Boca Raton, USA.

Kitchell, J.F., Hodgson, J.R., Cochran, P.A., Elser, J.J., Elser, M.M., Lodge, D.M., Von Ende, 
C.N., 1987. Regulation of lake primary productivity by food web structure. Ecology, 68 (6), 1863-1876. https://doi.org/10.2307/1939878.

Kleppel, G., 1995. Egg production and the nutritional environment of Acartia tonsa: The role of food quality in copepod nutrition. ICES J. Mar. Sci. 52 (3-4), 297-304. https://doi.org/10.1016/1054-3139(95)80045-X.

Kleppel, G.S., Burkart, C.A., Houchin, L., 1998. Nutrition and the regulation of egg production in the Calanoid copepod Acartia tonsa. Limnol. Oceanogr. 43 (5), 1000-1007. https://doi.org/10.4319/lo.1998.43.5.1000.

Koski, M., Breteler, W.K., Schogt, N., Gonzalez, S., Jakobsen, H.H., 2006. Life-stage-specific differences in exploitation of food mixtures: Diet mixing enhances copepod egg production but not juvenile development. J. Plankton Res. 28 (10), 919-936. https://doi.org/10.1093/plankt/fb1029.

Kulkarni, D., Gergs, A., Hommen, U., Ratte, H.T., Preuss, T.G., 2013. A plea for the use of copepods in freshwater ecotoxicology. Environ. Sci. Pollut. Int. 20 (1), 75-85. https://doi.org/10.1007/s11356-012-1117-4.

Kwok, K.W.H., Souissi, S., Dur, G., Won, E.J., Lee, J.S., 2015. Copepods as references Species in estuarine and marine waters, in: Amiard-Triquet, C., Amiard, J.C., Mouneyrac, C. (Eds.), Aquatic ecotoxicology : advancing tools for dealing with emerging risks. Academic Press, London, pp. 281-308. https://doi.org/10.1016/B978-0-12-8009499.00012-7.

Laabir, M., Poulet, S.A, Ianora, A., 1995. Measuring production and viability of eggs in Calanus helgolandicus. J. Plankton Res. 5, 1125-1142.

Laabir, M., Buttino, I., Ianora, A., Kattner, G., Poulet, S. A., Romano, G., Carotenuto, Y., Miralto, A., 2001. Effect of specific dinoflagellate and diatom diets on gamete ultrastructure and fatty acid profiles of the copepod Temora stylifera. Mar. Biol. 138, 1241-1250.

Lankov, A., Ojaveer, H., Simm, M., Põllupüü, M., Möllmann, C., 2010. Feeding ecology of pelagic fish species in the Gulf of Riga (Baltic Sea): The importance of changes in the zooplankton community. J. Fish Biol. 77 (10), 2268-2284. https://doi.org/10.1111/j.1095-8649.2010.02805.x.

Legendre, L., Rivkin, R.B., 2005. Integrating functional diversity, food web processes, and biogeochemical carbon fluxes into a conceptual approach for modeling the upper ocean in a high- $\mathrm{CO}_{2}$ world. J. Geophys. Res. 110, C09S17. https://doi.org/10.1029/2004JC002530. 
Li, J., Sun, S., Li, C., Zhang, Z., Pu, X., 2008. Effects of different diets on the reproduction and naupliar development of the copepod Acartia bifilosa. J. Exp. Mar. Biol. Ecol. 355 (2), 95-102. https://doi.org/10.1016/j.jembe.2007.12.005.

Lincoln, J.A., Turner, J.T., Bates, S.S., Léger, C., Gauthier, D.A., 2001. Feeding, egg production and egg hatching success of the copepods Acartia tonsa and Temora longicornis on diets of the toxic diatom Pseudo-nitzschia multiseries and the non-toxic diatom Pseudonitzschia pungens. Hydrobiologia 453-454, 107-120. https://doi.org/10.1023/A:1013163816771.

Lindley, J.A., Donkin, P., Evans, S.V.A., George, C.L.S., Uil, K.F., 1999. Effects of two organochlorine compounds on hatching and viability of calanoid copepod eggs. J. Exp. Mar. Biol. Ecol. 242 (1), 59-74. https://doi.org/10.1016/S0022-0981(99)00094-5.

Mahler, H.R., Cordes, E.H., 1968. Basic Biological Chemistry. Harper and Row, New York.

Manahan, S.E., 2010. Environmental chemistry, ninth ed. Boca Raton, CRC Press. Taylor and Francis Group. 753 pp.

Mauchline, J., 1998. The biology of calanoid copepods. Adv. Mar. Biol. 33, 1-170.

McKinnon, A.D., Duggan, S., Nichols, P.D., Rimmer, M.A., Semmens, G., Robino, B., 2003. The potential of tropical paracalanid copepods as live feeds in aquaculture. Aquaculture, 223 (1-4), 89-106. https://doi.org/10.1016/S0044-8486(03)00161-3.

Michalec, F.G., Holzner, M., Menu, D., Hwang, J.-S., Souissi, S., 2013. Behavioral responses of the estuarine calanoid copepod Eurytemora affinis to sub-lethal concentrations of waterborne pollutants. Aquat. Toxicol. 138-139, 129-138. https://doi.org/10.1016/j.aquatox.2013.05.007.

Milione, M., Zeng, C., 2007. The effects of algal diets on population growth and egg hatching success of the tropical calanoid copepod, Acartia sinjiensis. Aquaculture 273 (4), 656664. https://doi.org/10.1016/j.aquaculture.2007.07.014.

Miralto, A., Barone, G., Romano, G., Poulet, S.A., Ianora, A., Russo, G., Buttino, I., Mazzarella, G., Laabir, M., Cabrini, M., Giaccobe, M.G., 1999. The insidious effect of diatoms on copepod reproduction. Nature 402, 173. https://doi.org/10.1038/46023.

N'doua Etilé, R., Kassi Blahoua, G., Aké Bédia, T., Essetchi Kouamelan, P., N’Douba, V., 2017. Spatio-temporal variability of Acartia clausi (Copepoda, Calanoida) population structure, abundance, body length, and biomass in a tropical coastal lagoon (Grand-Lahou, Côte d'Ivoire). Int. J. Sci. 3 (06), 16-28. https://doi.org/10.18483/ijSci.1296.

Neffati, N., Daly Yahia-Kefi, O., Bonnet, D., Carlotti, F., Daly Yahia, M.N., 2013. Reproductive traits of two calanoid copepods: Centropages ponticus and Temora stylifera, in autumn in 
Bizerte Channel. J. Plankton Res. 35 (1), 80-96. https://doi.org/10.1093/plankt/fbs071.

Niemi, G.J., McDonald, M.E., 2004. Application of ecological indicators. Annu. Rev. Ecol. Evol. Syst. 35 (1), 89-111. https://doi.org/10.1146/annurev.ecolsys.35.112202.130132.

O'Bryen, P.J., Lee, C.S., 2005. Culture of copepods and applications to marine finfish larval rearing workshop discussion summary, in: Lee, C.S., O’Bryen, P. J., Marcus, N.H. (Eds.), Copepods in Aquaculture, Blackwell Publishing, Iowa, pp. 245-253. https://doi.org/10.1002/9780470277522.ch18.

Olivotto, I., Planas, M., Simões, N., Holt, G.J., Avella, M.A., Calado, R., 2011. Advances in breeding and rearing marine ornamentals. J. World Aquac. Soc. 42 (2), 135-166. https://doi.org/10.1111/j.1749-7345.2011.00453.x.

Ostrowski, A.C., Laidley, C.W., 2001. Application of marine food fish techniques in marine ornamental aquaculture: Reproduction and larval first feeding. Aquarium Sci. Conserv. 3 (1), 191-204. https://doi.org/10.1023/A:1011349931035.

Ott, F.S., Harris, R.P., O'Hara, S.C.M., 1978. Acute and sublethal toxicity of naphthalene and three methylated derivatives to the estuarine copepod, Eurytemora affinis. Mar. Environ. Res. 1 (1), 49-58. https://doi.org/10.1016/0141-1136(78)90013-2.

Pace, M.L., Cole, J.J., Carpenter, S.R., Kitchell, J.F., Hodgson, J.R., Van De Bogert, M.C., Bade D.L., Kritzberg, E.S., Bastviken, D., 2004. Whole-lake carbon-13 additions reveal terrestrial support of aquatic food webs. Nature 427 (6971), 240-243. https://doi.org/10.1038/nature02227.

Pagano, M., Kouassi, E., Arfi, R., Bouvy, M., Saint-Jean, L., 2004. In situ spawning rate of the Calanoid copepod Acartia clausi in a tropical lagoon (Ebrié, Côte dIvoire): Diel variations and effects of environmental factors. Zool. Stud. 43 (2), 244-254.

Pane, L., Boccardo, S., Bonfiglioli, F., Mariottini, G.L., Priano, F., Conio, O., 2005. Polycyclic aromatic hydrocarbons in water, seston and copepods in a harbour area in the Western Mediterranean (Ligurian Sea). Mar. Ecol. 26 (2), 89-99. https://doi.org/10.1111/j.14390485.2005.00042.x.

Parmar, T.K., Deepak, R., Agrawal, Y.K., 2016. Bioindicators: the natural indicator of $\begin{array}{llllll}\text { environmental pollution. } & \text { Front. Life } & \text { Sci. } 9 & \text { (2), 110- }\end{array}$ 118. https://doi.org/10.1080/21553769.2016.1162753.

Perry, R., Batchelder, H., Mackas, D., Chiba, S., Durbin, E., Greve, W., Verheye, H., 2004. Identifying global synchronies in marine zooplankton populations: Issues and $\begin{array}{llllll}\text { opportunities. } & \text { ICES J. } & \text { Mar. } & \text { Sci. } 61 & \text { (4), 445-456. }\end{array}$ https://doi.org/10.1016/j.icesjms.2004.03.022. 
Raisuddin, S., Kwok, K.W.H., Leung, K.M.Y., Schlenk, D., Lee, J.S., 2007. The copepod Tigriopus: A promising marine model organism for ecotoxicology and environmental $\begin{array}{lllll}\text { genomics. } & \text { Aquat. } & \text { Toxicol. } & 83 & \text { (3), }\end{array}$ https://doi.org/10.1016/j.aquatox.2007.04.005.

Reeve, M.R., Walter, M.A., Darcy, K., Ikeda, T., 1977. Evaluation of potential indicators of sublethal toxic stress on marine zooplankton (Feeding, fecundity, respiration, and excretion): Controlled ecosystem pollution experiment. Bull. Mar. Sci. 27, 105-113.

Reinfelder, J.R., Fisher, N.S., Luoma, S.N., Nichols, J.W., Wang, W.X., 1998. Trace element trophic transfer in aquatic organisms: A critique of the kinetic model approach. Sci. Total Environ. 219 (2-3), 117-135. https://doi.org/10.1016/s0048-9697(98)00225-3.

Reiss, C., McLaren, I., Avendano, P., Taggart, C., 2005. Feeding ecology of silver hake larvae on the Western Bank, Scotian Shelf, and comparison with Atlantic Cod. J. Fish Biol. 66 (3), 703-720. https://doi.org/10.1111/j.0022-1112.2005.00631.x.

Richardson, A.J., 2008. In hot water: Zooplankton and climate change. ICES J. Mar. Sci. 65 (3), 279-295. https://doi.org/10.1093/icesjms/fsn028.

Rodriguez, V., Guerreo, F., Bautista, B., 1995. Egg production of individual copepods of Acartia grani Sars from coastal waters: Seasonal and diel variability. J. Plankton Res. 17 (12), 2233-2250. https://doi.org/10.1093/plankt/17.12.2233.

Rombouts, I., Beaugrand, G., Artigas, L.F., Dauvin, J.C., Gevaert, F., Goberville, E., Kopp, D., Lefebvre, S., Luczak, Ch., Spilmont, N., Travers-Trolet, M., Villanueva, M.C., Kirby, R.R., 2013. Evaluating marine ecosystem health: Case studies of indicators using direct observations and modelling methods. Ecol. Indic. 24, 353-365.

Santhanam, P., Perumal, P., 2012. Feeding, survival, egg production and hatching rate of the marine copepod Oithona rigida Giesbrecht (Copepoda: Cyclopoida) under experimental conditions. J. Mar. Biol. Assoc. India $54 \quad$ (1), 8. https://doi.org/10.6024/jmbai.2012.54.1.01684-06.

Sedlacek, C., Marcus, N.H., 2005. Egg production of the copepod Acartia tonsa: The influence of hypoxia and food concentration. J. Exp. Mar. Biol. Ecol. 318 (2), 183-190. https://doi.org/10.1016/j.jembe.2004.12.012.

Sekiguchi, H., McLaren, I.A., Corkett, C.J., 1980. Relationship between growth rate and egg production in the copepod Acartia clausi. Mar. Biol. 58 (2), 133-138. https://doi.org/10.1007/BF00396124.

Serranito, B., Aubert, A., Stemmann, L., Rossi, N., Jamet, J.L., 2016. Proposition of indicators of anthropogenic pressure in the Bay of Toulon (Mediterranean Sea) based on zooplankton 
time-series. Cont. Shelf Res. 121, 3-12. https://doi.org/10.1016/j.csr.2016.01.016.

Soliman, Y.S., Al Ansari, E.M.S. Wade, T.L., 2014. Concentration, composition and sources of PAHs in the coastal sediments of the exclusive economic zone (EEZ) of Qatar, Arabian Gulf. Mar. Pollut. Bull. 85, 542-548. https://doi.org/10.1016/j.marpolbul.2014.04.027.

Soliman Y.S., Al Ansari, E.M.S., Sericano, J.L. and Wade, T.L., 2019. Spatio-temporal distribution and sources identifications of polycyclicaromatic hydrocarbons and their alkyl homolog in surface sediments in the central Arabian Gulf. Sci. Total Environ. 658, 787-797. https://doi.org/10.1016/j.scitotenv.2018.12.093.

Sørensen, T. F., Drillet, G., Engell-Sørensen, K., Hansen, B. W., Ramløv, H., 2007. Production and biochemical composition of eggs from neritic calanoid copepods reared in large outdoor tanks (Limfjord, Denmark). Aquaculture 263 (1-4), 84-96. https://doi.org/10.1016/j.aquaculture.2006.12.001.

Sosnowski, S. L., Gentile, J. H., 1978. Toxicological Comparison of Natural and Cultured Populations of Acartia tonsa to Cadmium, Copper, and Mercury. J. Fish. Res. Board Can. 35 (10), 1366-1369. https://doi.org/10.1139/f78-214.

Souissi, A., Souissi, S., Daly Yahia, M. N., 2008. Temporal variability of abundance and reproductive traits of Centropages kroyeri (Calanoida; Copepoda) in Bizerte Channel (SW Mediterranean Sea, Tunisia). J. Exp. Mar. Biol. Ecol. 355 (2), 125-136. https://doi.org/10.1016/j.jembe.2007.12.011.

Steinberg, D. K., Landry, M.R., 2017. Zooplankton and the Ocean Carbon Cycle. Ann Rev Mar Sci 9 (1), 413-444. https://doi.org/10.1146/annurev-marine-010814-015924.

Stottrup, J.G., 2000. The elusive copepods: Their production and suitability in marine aquaculture. Aquac. Res. 31 (8-9), 703-711. https://doi.org/10.1046/j.13652109.2000.00488.x.

Sullivan, B.K., Buskey, E., Miller, D.C., Ritacco, P. J., 1983. Effects of copper and cadmium on growth, swimming and predator avoidance in Eurytemora affinis (Copepoda). Mar. Biol. 77 (3), 299-306. https://doi.org/10.1007/BF00395819.

Sunda, W.G., Tester, P.A., Huntsman, S.A., 1987. Effects of cupric and zinc ion activities on the survival and reproduction of marine copepods. Mar. Biol. 94 (2), 203-210. https://doi.org/10.1007/BF00392932.

Tett, P., Carreira, C., Mills, D.K., van Leeuwen, S., Foden, J., Bresnan, E., Gowen, R.J., 2008. Use of a Phytoplankton Community Index to assess the health of coastal waters. ICES J. Mar. Sci. 65 (8), 1475-1482. https://doi.org/10.1093/icesjms/fsn161

Turner, J.T., 2004. The importance of small planktonic copepods and their roles in pelagic 
marine food webs. Zool. Stud. 42 (2), 255-266.

Urabe, J., Elser, J.J., Kyle, M., Yoshida, T., Sekino, T., Kawabata, Z., 2002. Herbivorous animals can mitigate unfavourable ratios of energy and material supplies by enhancing nutrient recycling. Ecol. Lett. 5 (2), 177-185. https://doi.org/10.1046/j.14610248.2002.00303.x.

Uye, S., 2011. Human forcing of the copepod-fish-jellyfish triangular trophic relationship. Hydrobiologia 666, 71-83.

Van Gestel, C.A.M., Loureiro, S., Zidar, P., 2018. Terrestrial isopods as model organisms in soil $\begin{array}{lllll}\text { ecotoxicology: } & \text { a } & \text { review. } & \text { ZooKeys } & \text { 127-162. }\end{array}$ https://doi.org/10.3897/zookeys.801.21970.

Vanzoest, R., Vaneck, G., 1991. Occurrence and behaviour of several groups of organic micropollutants in the Scheldt estuary. Sci. Total Environ. 103 (1), 57-71. https://doi.org/10.1016/0048-9697(91)90353-G.

Verity, P., Smetacek, V., 1996. Organism life cycles, predation, and the structure of marine pelagic ecosystems. Mar. Ecol. Prog. Ser. 130, 277-293. https://doi.org/10.3354/meps130277.

Verriopoulos, G., Moraitou-Apostolopoulou, M., 1982. Differentiation of the sensitivity to copper and cadmium in different life stages of a copepod. Mar. Pollut. Bull. 13 (4), 123125. https://doi.org/10.1016/0025-326X(82)90368-X.

Walker, C.H., 1990. Kinetic Models to Predict Bioaccumulation of Pollutants. Funct. Ecol. 4 (3), 295. https://doi.org/10.2307/2389589.

Walker, C.H., Sibly, R., Hopkin, S.P., Peakall, D., 2004. Principles of Ecotoxicology, second ed. Taylor and Francis Group, London.

Wang, W.X., Fisher, N.S., 1998. Accumulation of trace elements in a marine copepod. Limnol. Oceanogr. 43 (2), 273-283. https://doi.org/10.4319/lo.1998.43.2.0273.

Willis, K.J., Ling, N., 2004. Toxicity of the aquaculture pesticide cypermethrin to planktonic marine copepods. Aquac. Res., 35 (3), 263-270. https://doi.org/10.1111/j.13652109.2004.01008.x.

Wright, D.A., Welbourn, P., 2002. Environmental toxicology. New York, Cambridge University Press. 621 pp. http://dx.doi.org/10.1017/CBO9780511805998.

Zaleha, K., Ibrahim, B., John, B.A., Kamaruzzam, B.Y., 2012. Generation Time of Some Marine Harpacticoid Species in Laboratory Condition. J. Biol. Sci. 12 (8), 433-437. https://doi.org/10.3923/jbs.2012.433.437. 


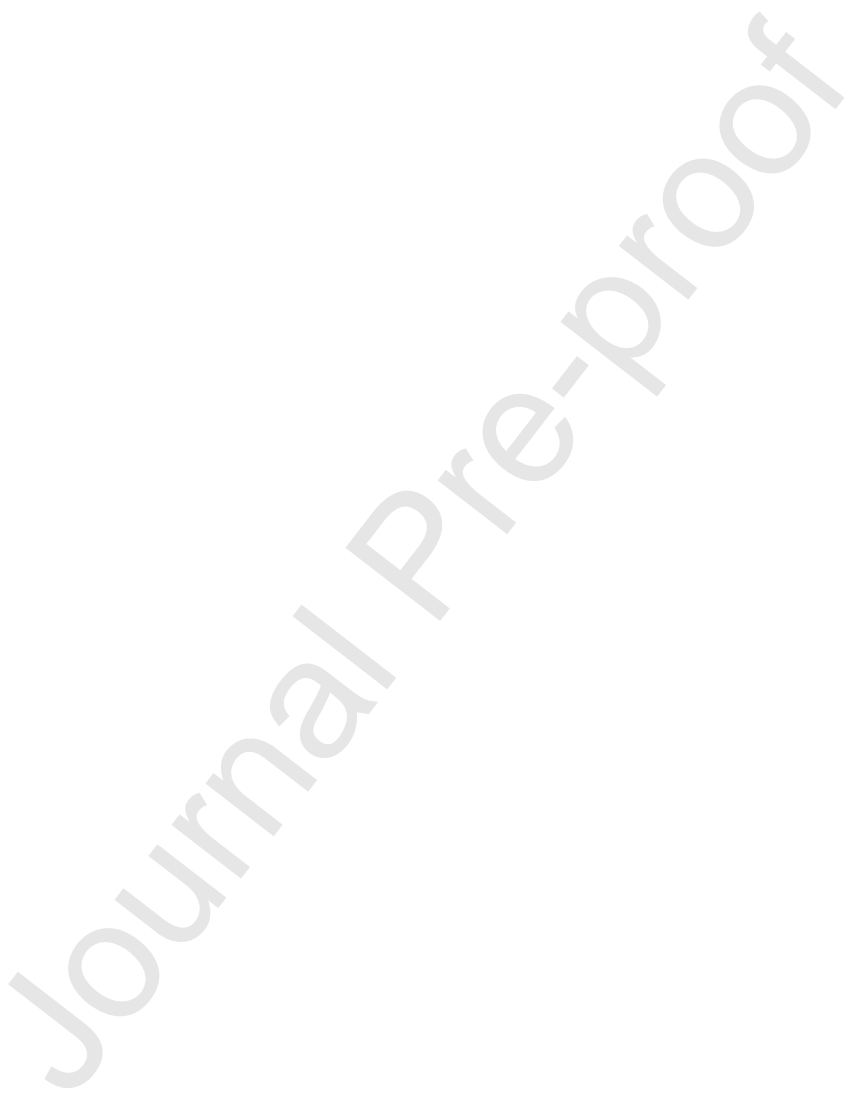




\section{CRT-INDEX (\%)}

100.00

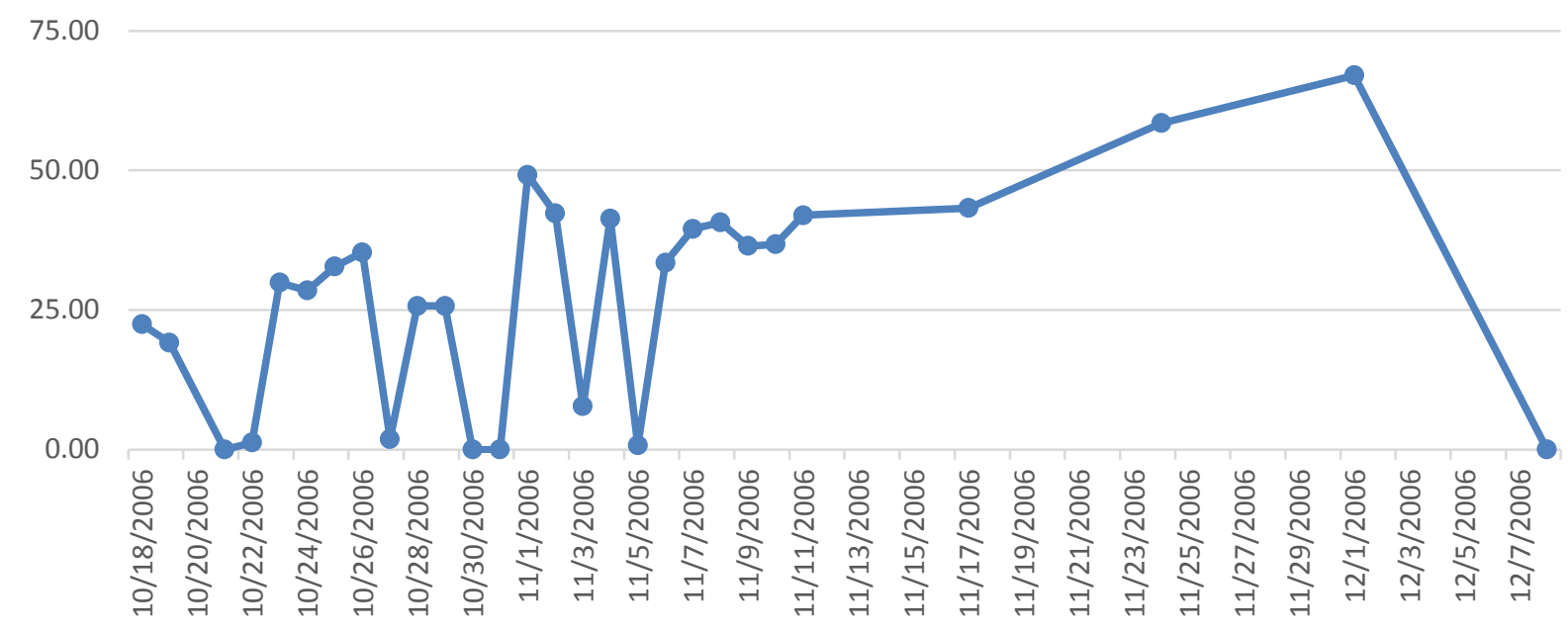

Figure 1. CRT-INDEX for Temora stylifera in Bizerte Channel (applied on data extracted from Neffati et al., 2013). 


\section{CRT-INDEX (\%)}

100.00

75.00

50.00

25.00

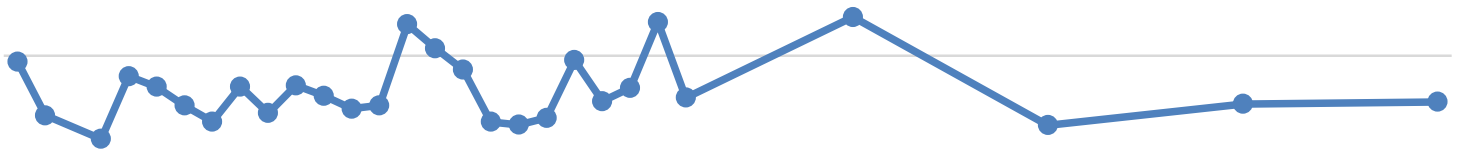

0.00

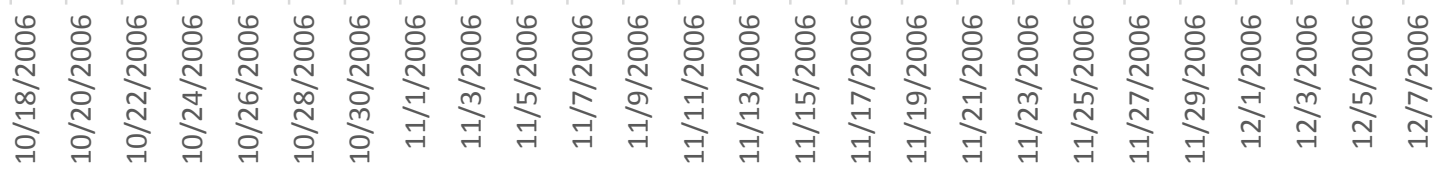

Figure 2. CRT-INDEX for Centropages ponticus in Bizerte Channel (applied on data extracted from Neffati et al., 2013). 
Table 1. Natural Egg Production Rates, Hatching Success and Nauplius Survival Rate in various study areas.

\begin{tabular}{|c|c|c|c|c|c|c|}
\hline Species & $\begin{array}{l}\text { Temperature } \\
\left({ }^{\circ} \mathrm{C}\right)\end{array}$ & $\begin{array}{l}\text { Egg Production } \\
\text { Rate (\# of eggs } \\
\text { female }^{-1} \text { day }^{-1} \text { ) }\end{array}$ & $\begin{array}{c}\text { Hatching } \\
\text { Success (\# of } \\
\text { nauplii } \\
\text { hatched after } \\
48 \mathrm{~h} \text { in } \% \text { ) }\end{array}$ & $\begin{array}{c}\text { Nauplii } \\
\text { Survival Rate } \\
\text { (\# of survival } \\
\text { nauplii } 24 \mathrm{~h} \\
\text { after hatching } \\
\text { in } \% \text { ) }\end{array}$ & Study Area & Authors \\
\hline \multicolumn{7}{|l|}{ Acartia } \\
\hline $\begin{array}{l}\text { A. bifilosa } \\
\text { (Giesbrecht, } \\
\text { 1881) }\end{array}$ & $4-15$ & $2.8-10.7$ & & & Baltic Sea & $\begin{array}{l}\text { Hansen et al., } \\
2006\end{array}$ \\
\hline A. bifilosa & 12 & $0.1-7.7$ & & & Yellow Sea & $\begin{array}{l}\text { Li \& Sun, } \\
2008\end{array}$ \\
\hline $\begin{array}{l}\text { A. clausi } \\
\text { (Giesbrecht, } \\
\text { 1889) }\end{array}$ & $15-20$ & $20-30$ & & & Baltic Sea & $\begin{array}{l}\text { Halsband \& } \\
\text { Hirche, } 2001\end{array}$ \\
\hline A. clausi & $13-14$ & $18-35$ & & & $\begin{array}{l}\text { Mediterranean } \\
\text { Sea }\end{array}$ & $\begin{array}{l}\text { Calbet et al., } \\
2002\end{array}$ \\
\hline A. clausi & $10-28$ & $8-60$ & & & $\begin{array}{l}\text { Ebrie Lagoon, } \\
\text { Gulf of } \\
\text { Guinea }\end{array}$ & $\begin{array}{l}\text { Pagano et al., } \\
2004\end{array}$ \\
\hline $\begin{array}{l}\text { A. tonsa } \\
\text { (Dana, 1848) }\end{array}$ & $17-24$ & $1.6-51.6$ & & & $\begin{array}{l}\text { Narrangansett } \\
\text { Bay }\end{array}$ & $\begin{array}{l}\text { Durbin et al., } \\
1983\end{array}$ \\
\hline A. tonsa & $14-20$ & $0.2-2.8$ & & & $\begin{array}{l}\text { Shediac Bay, } \\
\text { Northumberla } \\
\text { nd Strait, } \\
\text { Canada }\end{array}$ & $\begin{array}{l}\text { Lincoln et al., } \\
2001\end{array}$ \\
\hline A. tonsa & 20 & $25-70$ & & & Florida, USA & $\begin{array}{l}\text { Sedlacek \& } \\
\text { Marcus, } 2005\end{array}$ \\
\hline A. tonsa & 6-10 & $10-20$ & & & $\begin{array}{l}\text { Limfjord, } \\
\text { Denmark }\end{array}$ & $\begin{array}{l}\text { Sørensen et } \\
\text { al., } 2007\end{array}$ \\
\hline $\begin{array}{l}\text { A. hudsonica } \\
\text { Pinhey, } 1926\end{array}$ & $2.4-19.9$ & $2-20$ & & & $\begin{array}{l}\text { Bedford } \\
\text { Basin, Canada }\end{array}$ & $\begin{array}{l}\text { Sekiguchi et } \\
\text { al., } 1980\end{array}$ \\
\hline $\begin{array}{l}\text { A. grani Sars, } \\
1904\end{array}$ & $13.5-18$ & $5-79$ & & & $\begin{array}{l}\text { Mediterranean } \\
\text { Sea }\end{array}$ & $\begin{array}{l}\text { Rodriguez et } \\
\text { al., } 1995\end{array}$ \\
\hline \multicolumn{7}{|l|}{ Centropages } \\
\hline $\begin{array}{l}\text { C. ponticus } \\
\text { Karavaev, } \\
1895 \\
\end{array}$ & & $\begin{array}{l}8.7-19.3(13.7 \\
\pm 0.3)\end{array}$ & $\begin{array}{l}3-49(24.4 \pm \\
1.6)\end{array}$ & 26.6 & $\begin{array}{l}\text { Mediterranean } \\
\text { Sea }\end{array}$ & $\begin{array}{l}\text { Neffati et al., } \\
2013\end{array}$ \\
\hline $\begin{array}{l}\text { C. kroyeri } \\
\text { (Giesbrecht, } \\
1892 \text { ) }\end{array}$ & $15.1-23.3$ & 12.2 & & 11.8 & $\begin{array}{l}\text { Bizerte } \\
\text { Channel (SW } \\
\text { Mediterranean } \\
\text { Sea) } \\
\end{array}$ & $\begin{array}{l}\text { Souissi et al., } \\
2008\end{array}$ \\
\hline $\begin{array}{l}\text { C. typicus } \\
\text { Kroyer, } 1849\end{array}$ & 15 & $20-25$ & & & $\begin{array}{l}\text { Bay of } \\
\text { Villefranche- }\end{array}$ & $\begin{array}{l}\text { Carlotti et al., } \\
1997\end{array}$ \\
\hline
\end{tabular}




\begin{tabular}{|c|c|c|c|c|c|c|}
\hline & 20 & $35-40$ & & & sur-Mer & \\
\hline \multicolumn{7}{|l|}{ Paracartia } \\
\hline \multirow{3}{*}{$\begin{array}{l}\text { P. grani Sars, } \\
1904\end{array}$} & Summer & $4.43 \pm 0.7$ & \multirow{3}{*}{-} & \multirow{3}{*}{-} & \multirow{3}{*}{$\begin{array}{l}\text { North Lagoon } \\
\text { of Tunis }\end{array}$} & \multirow{3}{*}{$\begin{array}{l}\text { Annabi- } \\
\text { Trabelsi et } \\
\text { al., } 2012\end{array}$} \\
\hline & Autumn & $7.9 \pm 0.6$ & & & & \\
\hline & Winter & $2.08 \pm 0.5$ & & & & \\
\hline \multirow{2}{*}{$\begin{array}{l}P . \text { latisetosa } \\
\text { (Krichagrin, } \\
1873 \text { ) }\end{array}$} & Summer & $13.1 \pm 6.1$ & \multirow{2}{*}{-} & \multirow{2}{*}{ 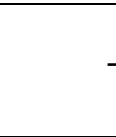 } & \multirow{2}{*}{$\begin{array}{l}\text { North Lagoon } \\
\text { of Tunis }\end{array}$} & \multirow{2}{*}{$\begin{array}{l}\text { Annabi- } \\
\text { Trabelsi et } \\
\text { al., } 2012 \\
\end{array}$} \\
\hline & Autumn & $4.49 \pm 0.6$ & & & & \\
\hline \multicolumn{7}{|l|}{ Temora } \\
\hline $\begin{array}{l}\text { T. stylifera } \\
\text { Dana, } 1849\end{array}$ & 22 & 35 & & & $\begin{array}{l}\text { Mediterranean } \\
\text { Sea }\end{array}$ & $\begin{array}{l}\text { Halsband- } \\
\text { Lenk et al., } \\
2001\end{array}$ \\
\hline T. stylifera & 23 & 35 & & & $\begin{array}{l}\text { Mediterranean } \\
\text { Sea }\end{array}$ & $\begin{array}{l}\text { Halsband- } \\
\text { Lenk et al., } \\
2004\end{array}$ \\
\hline T. stylifera & 15 & 25.7 & & & North Sea & $\begin{array}{l}\text { Halsband- } \\
\text { Lenk et al., } \\
2002\end{array}$ \\
\hline T. stylifera & & $\begin{array}{l}3-89(35.2+- \\
3.8)\end{array}$ & $\begin{array}{l}30-97.8(50.4 \\
+-5.5)\end{array}$ & 34.9 & $\begin{array}{l}\text { Mediterranean } \\
\text { Sea }\end{array}$ & $\begin{array}{l}\text { Neffati et al., } \\
2013\end{array}$ \\
\hline
\end{tabular}

Table 2 Correlation coefficients (r, Statistical) between copepod reproductive traits and environmental factors for different key marine and coastal copepod species in natural conditions. $(+)^{*}$ : positive significative correlation; $(+)^{* *}$ : positive highly significative correlation; $(-)^{*}$ : negative significative correlation; (-)**: negative highly significative correlation; NS: non 
significative.

\begin{tabular}{|c|c|c|c|c|c|c|}
\hline Species & $\begin{array}{l}\text { Reproductive } \\
\text { Traits }\end{array}$ & Temperature & Salinity & Chla & POC & Study \\
\hline $\begin{array}{l}\text { Acartia clausi } \\
\text { (Giesbrecht, 1889) }\end{array}$ & EPR & $-0.88 * *$ & -0.87 & +0.74 & +0.20 & $\begin{array}{l}\text { Annabi- } \\
\text { Trabelsi, } \\
2009\end{array}$ \\
\hline $\begin{array}{l}\text { Paracartia } \\
\text { latisetosa } \\
\text { (Krichagrin, 1873) }\end{array}$ & EPR & $+0.64 * *$ & $+0.66 * *$ & -0.17 & $+0.42^{* * *}$ & $\begin{array}{l}\text { Annabi- } \\
\text { Trabelsi, } \\
2009\end{array}$ \\
\hline $\begin{array}{l}\text { Paracartia grani } \\
\text { Sars, } 1904\end{array}$ & EPR & $+0.89^{* *}$ & $+0.90^{* *}$ & +0.19 & $+0.41^{* * *}$ & $\begin{array}{l}\text { Annabi- } \\
\text { Trabelsi, } \\
2009\end{array}$ \\
\hline $\begin{array}{l}\text { Centropages } \\
\text { kroyeri } \\
\text { (Giesbrecht, 1892) }\end{array}$ & EPR & -0.081 & $+0.284^{*}$ & -0.045 & N/A & $\begin{array}{l}\text { Souissi et } \\
\text { al., } 2008\end{array}$ \\
\hline $\begin{array}{l}\text { Centropages } \\
\text { kroyeri }\end{array}$ & HS & +0.227 & $+0.0304^{*}$ & $+0.556^{* * * *}$ & N/A & $\begin{array}{l}\text { Souissi et } \\
\text { al., } 2008\end{array}$ \\
\hline $\begin{array}{l}\text { Centropages } \\
\text { kroyeri }\end{array}$ & NSR (24h) & -0.180 & +0.066 & +0.012 & N/A & $\begin{array}{l}\text { Souissi et } \\
\text { al., } 2008\end{array}$ \\
\hline $\begin{array}{l}\text { Centropages } \\
\text { kroyeri }\end{array}$ & NSR (48h) & $+0.364 * *$ & +0.077 & -0.080 & N/A & $\begin{array}{l}\text { Souissi et } \\
\text { al., } 2008\end{array}$ \\
\hline $\begin{array}{l}\text { Centropages } \\
\text { ponticus } \\
\text { Karavaev, } 1895 \\
\end{array}$ & EPR & & ---- & ---- & N/A & $\begin{array}{l}\text { Neffati et } \\
\text { al., } 2013\end{array}$ \\
\hline $\begin{array}{l}\text { Centropages } \\
\text { ponticus }\end{array}$ & $\mathrm{HS}$ & $-1-$ & ---- & $-0.39 * *$ & N/A & $\begin{array}{l}\text { Neffati et } \\
\text { al., } 2013\end{array}$ \\
\hline $\begin{array}{l}\text { Centropages } \\
\text { ponticus }\end{array}$ & NSR (24h) & $-0.49^{* *}$ & --- & ---- & N/A & $\begin{array}{l}\text { Neffati et } \\
\text { al., } 2013\end{array}$ \\
\hline $\begin{array}{l}\text { Centropages } \\
\text { ponticus }\end{array}$ & NSR (48h) & $+0.67 * *$ & --- & ---- & N/A & $\begin{array}{l}\text { Neffati et } \\
\text { al., } 2013\end{array}$ \\
\hline $\begin{array}{l}\text { Temora stylifera } \\
\text { Dana, } 1849\end{array}$ & EPR & ---- & ---- & ---- & N/A & $\begin{array}{l}\text { Neffati et } \\
\text { al., } 2013\end{array}$ \\
\hline Temora stylifera & HS & --- & --- & --- & N/A & $\begin{array}{l}\text { Neffati et } \\
\text { al., } 2013\end{array}$ \\
\hline Temora stylifera & NSR (24h) & ---- & --- & $-0.46^{* *}$ & N/A & $\begin{array}{l}\text { Neffati et } \\
\text { al., } 2013\end{array}$ \\
\hline Temora stylifera & NSR(48h) & $-0.41 * *$ & ---- & ---- & N/A & $\begin{array}{l}\text { Neffati et } \\
\text { al., } 2013\end{array}$ \\
\hline
\end{tabular}


Table 3 Consequence of Copper and Chromium on the daily egg production of various copepod species.

\begin{tabular}{|c|c|c|c|c|c|c|c|}
\hline Species & $\begin{array}{l}\text { Heavy } \\
\text { Metal }\end{array}$ & $\begin{array}{c}\text { Concentration } \\
\left(\mu \mathrm{g} \cdot \mathrm{L}^{-1}\right)\end{array}$ & $\begin{array}{l}\text { Day } 1 \\
(\text { Eggs })\end{array}$ & $\begin{array}{l}\text { Day } 3 \\
\text { (Eggs) }\end{array}$ & $\begin{array}{l}\text { Day } 5 \\
\text { (Eggs) }\end{array}$ & $\begin{array}{l}\text { Sampling } \\
\text { Station / } \\
\text { Study Site }\end{array}$ & Authors \\
\hline \multirow{5}{*}{$\begin{array}{l}\text { Mixed culture } \\
\text { of Acartia and } \\
\text { Paracalanus }\end{array}$} & \multirow{5}{*}{ 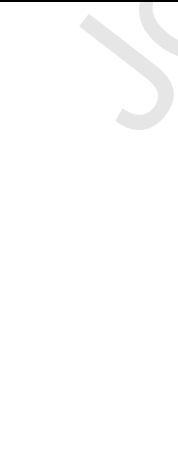 } & Control (0) & 89 & 62 & 54 & \multirow{5}{*}{$\begin{array}{l}\text { Saanich } \\
\text { Inlet, } \\
\text { British } \\
\text { Colombia }\end{array}$} & \multirow{5}{*}{$\begin{array}{l}\text { Reeve, } \\
1977\end{array}$} \\
\hline & & 10 & 62 & 60 & 41 & & \\
\hline & & 20 & 59 & 46 & 6 & & \\
\hline & & 50 & 10 & 23 & 0 & & \\
\hline & & 100 & 0 & 0 & 0 & & \\
\hline $\begin{array}{l}\text { Notodiaptomus } \\
\text { conifer (Sars, }\end{array}$ & Copper & & \multicolumn{3}{|c|}{$\begin{array}{l}\text { No. of eggs per female } \\
\text { (mean) }\end{array}$} & $\begin{array}{l}\text { Tanks from } \\
\text { the }\end{array}$ & $\begin{array}{l}\text { Gutierrez } \\
\text { et al., }\end{array}$ \\
\hline
\end{tabular}




\begin{tabular}{|c|c|c|c|c|c|}
\hline \multirow[t]{9}{*}{ 1901) } & & Control & 5.67 & \multirow{9}{*}{\begin{tabular}{|l} 
Instituto \\
Nacional \\
de \\
Limnología \\
(CONICET \\
UNL)
\end{tabular}} & \multirow[t]{9}{*}{2010} \\
\hline & & 0.4 & 7 & & \\
\hline & & 0.8 & 11.2 & & \\
\hline & & 1.6 & 7.5 & & \\
\hline & & 3 & - & & \\
\hline & Chromium & Control & 9.66 & & \\
\hline & & 7.5 & 3 & & \\
\hline & & 15 & & & \\
\hline & & 30 & & & \\
\hline
\end{tabular}

Table 4. Effect of $\mathrm{Hg}, \mathrm{Cd}$ and $\mathrm{Ag}$ on the Egg Production Rate (EPR) and Hatching Success (HS) of various copepod species.

\begin{tabular}{|c|c|c|c|c|c|c|c|}
\hline Species & $\begin{array}{l}\text { Heavy } \\
\text { Metal }\end{array}$ & $\begin{array}{l}\text { Concentration } \\
\qquad(\mu \mathrm{g} . \mathrm{L}-1)\end{array}$ & $\%$ of EPR & $\%$ of $\mathrm{HS}$ & $\mathrm{T}\left({ }^{\circ} \mathrm{C}\right)$ & $\begin{array}{l}\text { Sampling } \\
\text { Station / } \\
\text { Study Site }\end{array}$ & Authors \\
\hline \multirow{4}{*}{$\begin{array}{l}\text { Centropages } \\
\text { ponticus } \\
\text { Karavaev, } 1895\end{array}$} & \multirow{4}{*}{$\begin{array}{l}\text { Cadmium } \\
(48 \quad \mathrm{~h} \\
\text { exposure) }\end{array}$} & Control & $100 \%$ & $100 \%$ & \multirow[t]{4}{*}{18} & \multirow{4}{*}{$\begin{array}{l}\text { Bizerte } \\
\text { lagoon, } \\
\text { Tunisia }\end{array}$} & \multirow{4}{*}{$\begin{array}{l}\text { Ensibi et } \\
\text { al., } 2015\end{array}$} \\
\hline & & 0.2 & $57.75 \%$ & $59.64 \%$ & & & \\
\hline & & 0.4 & $31.76 \%$ & $39.25 \%$ & & & \\
\hline & & 1 & $22.52 \%$ & $13.09 \%$ & & & \\
\hline Species & $\begin{array}{l}\text { Heavy } \\
\text { Metal }\end{array}$ & $\begin{array}{c}\text { Concentration } \\
\text { (Nm - } \\
\text { Nanomols) }\end{array}$ & $\begin{array}{c}\text { EPR } \\
\text { (Individual }^{-1} \\
\left.\text { day }^{-1}\right)\end{array}$ & $\begin{array}{l}\text { HS (\% } \\
\text { control) }\end{array}$ & $\mathrm{T}\left({ }^{\circ} \mathrm{C}\right)$ & $\begin{array}{l}\text { Sampling } \\
\text { Station / } \\
\text { Study Site }\end{array}$ & Authors \\
\hline Acartia tonsa & Mercury & 0 & $100 \pm 10$ & $100 \pm 15$ & $15-25$ & Stony & Hook \\
\hline
\end{tabular}




\begin{tabular}{|c|c|c|c|c|c|c|c|}
\hline \multirow{13}{*}{$\begin{array}{l}\text { (Dana, 1848) \& } \\
\text { A. hudsonica } \\
\text { Pinhey, } 1926\end{array}$} & & 0.25 & $52 \pm 7$ & $57 \pm 5$ & \multirow{13}{*}{$\begin{array}{l}\text { (Depending } \\
\text { on the } \\
\text { season) }\end{array}$} & \multirow{13}{*}{$\begin{array}{l}\text { Brook } \\
\text { Harbor, } \\
\text { New } \\
\text { York, } \\
\text { USA }\end{array}$} & \multirow{13}{*}{$\begin{array}{l}\text { Fisher, } \\
2001\end{array}$} \\
\hline & & 0.5 & $51 \pm 4$ & $56 \pm 9$ & & & \\
\hline & & 1 & $42 \pm 2$ & $58 \pm 7$ & & & \\
\hline & & 2 & $49 \pm 5$ & $53 \pm 4$ & & & \\
\hline & Cadmium & 0 & $100 \pm 14$ & $100 \pm 18$ & & & \\
\hline & & 0.25 & $89 \pm 10$ & $85 \pm 8$ & & & \\
\hline & & 0.5 & $92 \pm 23$ & $86 \pm 11$ & & & \\
\hline & & 1 & $106 \pm 22$ & $82 \pm 13$ & & & \\
\hline & & 2 & $115 \pm 20$ & $85 \pm 14$ & & & \\
\hline & Silver & 0 & $100 \pm 17$ & 100 & & & \\
\hline & & 0.25 & $91 \pm 16$ & 98 & & & \\
\hline & & 0.5 & $91 \pm 28$ & 110 & & & \\
\hline & & 1 & $110 \pm 32$ & 79 & & & \\
\hline
\end{tabular}

Table 5 Effects of organic contaminants on various species of copepods reproduction traits.

\begin{tabular}{|c|c|c|c|c|c|}
\hline Chemical & Species & $\begin{array}{l}\text { Concentration } \\
\left(\mu \mathrm{g} . \mathrm{L}^{-1}\right)\end{array}$ & Effects & $\begin{array}{c}\text { Exposure } \\
\text { Time } \\
\text { (Days) }\end{array}$ & Study \\
\hline Naphthalene & $\begin{array}{l}\text { Eurytemora } \\
\text { affinis } \\
\text { (Poppe, } \\
\text { 1880) }\end{array}$ & $10-50$ & $\begin{array}{l}\text { No sig. effect on } \\
\text { egg production }\end{array}$ & 10 & $\begin{array}{l}\text { Berdugo et al., } \\
1977\end{array}$ \\
\hline Naphthalene & $\begin{array}{l}\text { Eurytemora } \\
\text { affinis }\end{array}$ & 14.2 & $\begin{array}{l}\text { Reduction in EPR: } \\
43.7 \%\end{array}$ & $<29$ & Ott et al., 1978 \\
\hline 2-methylnaphthalene & $\begin{array}{l}\text { Eurytemora } \\
\text { affinis }\end{array}$ & 15.0 & $\begin{array}{l}\text { Reduction in EPR: } \\
43.3 \%\end{array}$ & $<29$ & Ott et al., 1978 \\
\hline 2,6-dimethylnaphthalene & $\begin{array}{l}\text { Eurytemora } \\
\text { affinis }\end{array}$ & 8.2 & $\begin{array}{l}\text { Reduction in EPR: } \\
35.1 \%\end{array}$ & $<29$ & Ott et al., 1978 \\
\hline 2,3,5-trimethylnaphthalene & $\begin{array}{l}\text { Eurytemora } \\
\text { affinis }\end{array}$ & 9.3 & $\begin{array}{l}\text { Reduction in EPR: } \\
52.1 \%\end{array}$ & $<29$ & Ott et al., 1978 \\
\hline
\end{tabular}


Table 6. Hatching Percentage of two Species of Calanoid Copepod under Pentachlorophenol (PCP) of $14 \mathrm{mg} \mathrm{l}^{-1} \& 1,2$-dichlorobenzene (DCB) of $91 \mathrm{mg} \mathrm{l}^{-1}$ and Filtered Sea Water (FSW) treatments.

\begin{tabular}{|c|c|c|c|c|}
\hline Species & Treatment & $\begin{array}{l}\text { Average number of } \\
\text { Eggs (Replicates) }\end{array}$ & $\begin{array}{l}\text { Hatching success } \\
\% \pm \mathrm{SD}\end{array}$ & Authors \\
\hline \multirow{4}{*}{$\begin{array}{l}\text { Eurytemora } \\
\text { affinis } \\
\text { (Poppe, } \\
1880 \text { ) }\end{array}$} & Control (FSW) & $132(5)$ & $>99 \pm 1$ & \multirow{8}{*}{$\begin{array}{l}\text { Lindley et al., } \\
1999\end{array}$} \\
\hline & DCB Solution & $209(5)$ & $<1 \pm 1$ & \\
\hline & FSW overnight & $112(3)$ & 100 & \\
\hline & DCB overnight & $239(3)$ & $36 \pm 53$ & \\
\hline \multirow{4}{*}{$\begin{array}{l}\text { Acartia } \\
\text { bifilosa } \\
\text { (Giesbrecht, } \\
1881 \text { ) }\end{array}$} & Control (FSW) & $15(3)$ & $68 \pm 28$ & \\
\hline & PCP Solution & $15(3)$ & 0 & \\
\hline & FSW overnight & $13(3)$ & $86 \pm 12$ & \\
\hline & PCP overnight & $15(3)$ & 0 & \\
\hline
\end{tabular}


Table 7 Proposed CRT-Index range and environment or tested pollutant levels of contamination or impacts.

\begin{tabular}{|c|c|}
\hline CRT-Index range $(\%)$ & Level of contamination or pollutant impact \\
\hline $75 \%<$ CPT-Index $<100 \%$ & Low Contamination or No Impact \\
\hline $50 \%<$ CPT-Index $<75 \%$ & Medium Contamination or Impact \\
\hline $25 \%<$ CPT-Index $<50 \%$ & High Contamination or Impact \\
\hline $0 \%<$ CPT-Index $<25 \%$ & Very High Contamination Impact \\
\hline
\end{tabular}




\section{Declaration of interests}

$\bigotimes$ The authors declare that they have no known competing financial interests or personal relationships that could have appeared to influence the work reported in this paper.

$\square$ The authors declare the following financial interests/personal relationships which may be considered as potential competing interests:

Graphical abstract

\section{Highlights}

- Response of some copepod species reproductive traits in natural contamination conditions.

- Impact of Inorganic Heavy Metals, Polycyclic Aromatic Hydrocarbons (PAHs)and Persistent Organic Pollutants (POPs) on planktonic copepods Egg Production Rate (EPR)

- Copepod Reproductive Trait - Index (CRT-Index) a new tool in aquatic ecotoxicology studies. 


\section{CRT-INDEX (\%)}

100.00

75.00

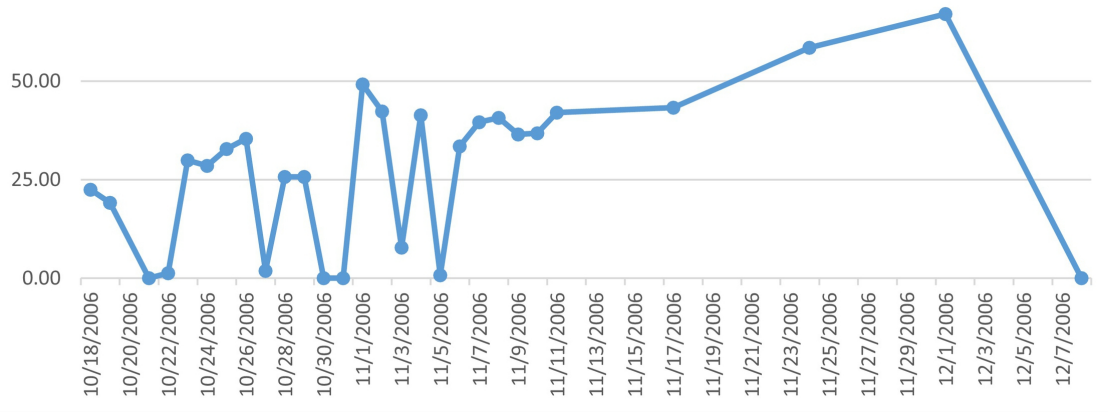

Figure 1 


\section{CRT-INDEX (\%)}

100.00

75.00

50.00

25.00

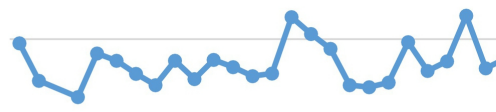

0.00

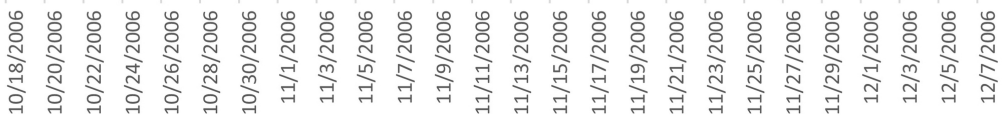

Figure 2 